\title{
Harmonic Uniformity and Hungarian front/back harmony
}

\author{
PÉTER REBRUS and MIKLÓS TÖRKENCZY*
}

Hungarian Research Centre for Linguistics, Eötvös Loránd University (ELTE), Budapest, Hungary

Received: March 3, 2021 • Revised manuscript received: May 7, 2021 • Accepted: May 15, 2021

Published online: July 9, 2021

(C) 2021 The Author(s)

\begin{abstract}
In the paper we argue against the traditional assumption about the relationship between morphology and harmony in Hungarian according to which monomorphemic and polymorphemic (suffixed) forms behave in the same way harmonically within the domain of harmony. We show that the harmonic properties of the root are inherited by morphologically complex forms based on the root and this can override the phonological restrictions on harmony. We propose an Optimality Theory analysis of the interaction between the phonological constraints on harmony and the paradigm uniformity constraint Harmonic Uniformity.
\end{abstract}

\section{KEYWORDS}

Hungarian, front/back harmony, variation, neutral vowels, Count Effect, Height Effect, Polysyllabic Split, Harmonic Uniformity, paradigm uniformity, harmonic domains, morphology-phonology interaction

\section{INTRODUCTION}

The traditional assumption about the relationship between vowel harmony and morphology in Hungarian is that (i) the domain of harmony is the (phonological) word, which is defined so that prefixes and some affixes fall outside the domain and the constituent parts of compounds form separate harmonic domains; furthermore, that (ii) morphologically simplex ${ }^{1}$ and complex

*Corresponding author. E-mail: tork@nytud.hu

${ }^{1}$ Assuming that disharmonic roots (e.g. Sofø:r 'chauffeur'), whose type frequency is very low, are exceptions to vowel harmony. 
forms behave in the same way harmonically within the domain of harmony as identified in (i) above (e.g. Siptár \& Törkenczy 2000).

However, the relationship between Hungarian vowel harmony $(\mathrm{HVH})$ and morphology is more complex than what is traditionally assumed: specifically, (a) domain boundaries that different phenomena refer to tend not to coincide (cf. Törkenczy 2011; Rebrus et al. 2012) ${ }^{2}$ and are not always categorical (e.g. "compoundness" may be gradient) and this can influence harmonic behaviour (Rebrus \& Törkenczy 2017a), and (b) within the harmonic domain the harmonic properties of the root are inherited by morphologically complex forms based on the root and this can even override the phonological restrictions on harmony such as the Height Effect, the Count Effect and the Polysyllabic Split, see Section 2. In this paper we explore the relationship between Hungarian front/back harmony and morphology focussing on the latter set of phenomena ((b) above), which we will refer to as Harmonic Uniformity (sometimes also referred to as harmonic consistency or harmonic stability, cf. Törkenczy et al. 2013; Rebrus \& Törkenczy 2017b; 2019 and Rebrus \& Szigetvári 2016; Rebrus et al. 2017; Törkenczy 2019). The analysis proposed does not attribute disharmony between stem and suffix to differences in harmonic domains and does not consider stem-internal disharmony as exceptional - thus both fall within the purview of the analysis.

The phenomena where $\mathrm{HVH}$ and Harmonic Uniformity interact in an interesting way concern transparency and antiharmony (cf. Section 2), i.e. situations where the neutral vowels $\mathbf{i}$, i:, e:, $\boldsymbol{\varepsilon}$ (which are phonetically front) occur in disharmonic strings. The paper is organised in the following way: in Section 2 we present a brief overview of the phonological aspect of front/back harmony background with the Height Effect, the Count Effect and the Polysyllabic Split in focus and in Section 3 we examine the interaction of Harmonic Uniformity with the phonological harmony patterns discussed in Section 2. In Section 4 we present an Optimality Theory analysis of front/back harmony and Harmonic Uniformity. We conclude with a summary in Section 5.

\section{BACKGROUND: FRONT/BACK HARMONY}

In this section we briefly summarise the phonological properties of and the phenomena associated with front/back harmony, which serve as a background to our main focus, harmonic uniformity.

The basic phonological facts of Hungarian front/back harmony are well-known (e.g. Törkenczy 2011; Rebrus \& Törkenczy 2019; for the literature see Törkenczy 2021): it is a rootcontrolled type of harmony in which vowels harmonise according to backness within the harmonic domain, usually identified as the phonological word (which excludes compounds and some affixes). Disharmony with the rounded front vowels $\boldsymbol{\emptyset}, \boldsymbol{\emptyset}, \mathbf{y}, \mathbf{y}$ : within the domain is avoided but there are neutral vowels, which systematically tolerate disharmony. In this paper we define neutrality empirically, based on the (type) frequency of disharmonic sequences in surface forms and not as a derivative of (some property of an) underlying representation (e.g. Siptár \& Törkenczy 2000). A vowel that frequently occurs in sequences of syllables where it disagrees in the harmonic property with the vowel of an adjacent syllable is a harmonically neutral vowel (N)

\footnotetext{
${ }^{2}$ The sheer number of alternations that are involved in these "domain mismatches" makes it impossible to make a domain-based analysis work in a non-stipulative way.
} 
and the disharmonic string in which it occurs is weakly disharmonic. The vowels that do not or rarely (unsystematically) occur in disharmony are the harmonic vowels (front ø, ø:, y, y: (F)) and back $\mathbf{u}, \mathbf{u}, \mathbf{o}, \mathbf{o :}, \mathbf{a}$, a: (B)) and the rare disharmonic strings in which they happen to occur are strongly disharmonic.

In Hungarian front/back harmony there are four neutral vowels (the unrounded front vowels i, i:, $\varepsilon, \mathbf{e})^{3}$, whose neutrality manifests itself in the following (potentially) disharmonic patterns: (a) root phonotactics: $\mathrm{N}$ vowels freely combine in disharmony in roots $\left([\ldots \mathrm{BN} \ldots],[\ldots \mathrm{NB} \ldots]^{4}\right.$, e.g. hamis 'false', vila:g 'world'; (b) antiharmony: some all-neutral roots require the B alternant of a harmonically alternating suffix ([N]B, e.g. di:j-at (*di:j-et) 'prize-ACC'); (c) transparency: after a $\mathrm{B}$ vowel, an $\mathrm{N}$ vowel is followed by a $\mathrm{B}$ vowel in a harmonically alternating suffix $([\ldots \mathrm{BN}] \mathrm{B}$, e.g. zokni-to:l ('zokni-tø:l) 'sock-ABL'); (d) invariance: the harmonically invariant suffixes (almost) exclusively have $\mathrm{N}$ vowels ([ . . B $] \mathrm{N}$, e.g. ha:z-ig 'house-TERM', ha:z-e:rt 'house-CAUs'). We show this in the table in (1) below, where each $\mathrm{N}$ vowel is evaluated separately. Cells with pluses are shaded; values in parentheses indicate that a few exceptions do occur.

(1) Neutral and harmonic behaviour

\begin{tabular}{|l|c|c|c|c|c|c|}
\hline & a. roots & b. antiharmony & \multicolumn{2}{|c|}{ c. transparency } & \multicolumn{2}{|c|}{ d. suffixes } \\
\cline { 2 - 7 } & $\begin{array}{c}\text { can occur in } \\
\text { disharmony with } \\
\text { harmonic V } \\
{[\mathrm{BN}],[\mathrm{NB}]}\end{array}$ & $\begin{array}{c}\text { can occur in } \\
\text { antiharmonic roots } \\
{[\mathrm{N}] \mathrm{B}}\end{array}$ & $\begin{array}{c}\text { can be } \\
\text { transparent } \\
{[\mathrm{BN}] \mathrm{B}}\end{array}$ & $\begin{array}{c}\text { cannot be } \\
\text { opaque } \\
{ }^{[\mathrm{BN}] \mathrm{F}}\end{array}$ & $\begin{array}{c}\text { can be } \\
\text { invariant } \\
{[\mathrm{F}] \mathrm{N} \sim[\mathrm{B}] \mathrm{N}}\end{array}$ & $\begin{array}{c}\text { cannot be } \\
\text { alternating } \\
{ }^{*}[\mathrm{~F}] \mathrm{N} \sim[\mathrm{B}] \mathrm{B}\end{array}$ \\
\hline $\mathrm{i}(:)$ & + & + & + & $+^{5}$ & + & $+{ }^{6}$ \\
\hline $\mathrm{e}:$ & + & + & + & - & + & - \\
\hline$\varepsilon$ & + & $-{ }^{7}$ & + & - & $-{ }^{8}$ & - \\
\hline F/B & $(-)$ & - & - & - & $(-)$ & - \\
\hline
\end{tabular}

Since the shaded cells in (1) mark prototypical neutral behaviour, it is clear that the neutral vowels show gradience in neutrality (from most neutral to least neutral): $\mathbf{i}(\mathbf{:})^{9}>\mathbf{e}: \mathbf{\varepsilon}$. Hayes \& Cziráky Londe (2006) has referred to this as the Height Effect only with respect to transparency, but it is clear

\footnotetext{
${ }^{3}$ Note that in the formal OT analysis in Section 4 we will introduce a further division of neutral vowels because of the intermediate properties of $\boldsymbol{\varepsilon}$.

${ }^{4}$ Square brackets mark morpheme boundaries in formulae.

${ }^{5}$ Except in very limited cases in foreign place names, where optionally a front suffix alternant can occur, e.g. minusinskban/ben 'Minusinsk-INE'; see Fejes \& Rebrus (2019).

${ }^{6}$ Except the suppletive SG3 definite -ja $\sim \mathbf{i}$ suffix, see Section 4.1 .

${ }^{7}$ Except in two bound stems: herv-, derek-, see below.

${ }^{8}$ Except in the diminutive suffixes - $\mathbf{\varepsilon s ,}-\boldsymbol{\varepsilon r}$, which are not agglutinative and not harmonically alternating, and therefore they are beyond the scope of this analysis (see Rebrus \& Szigetvári 2021).

${ }^{9}$ Long and short $\mathbf{i}(:)$ behave in the same way.
} 
that the Height Effect manifests itself in the other patterns of neutrality separately and in the overall tolerance of (weak) disharmony by $\mathrm{N}$ vowels involving all the four patterns (cf. Rebrus et al. 2020).

If we focus on the dynamic aspect of front/back harmony, i.e. suffix alternation (b, $c$ and $d$ in (1)), we find that phonology underdetermines suffix harmony when patterns with $\mathrm{N}$ vowels are involved. This manifests itself in variation: the same phonological conditions (vocalic patterns), specifically, the harmonic environments $[\mathrm{N}]_{-}$and $[\mathrm{BN}]_{-}$are associated with more than one kind of harmonic behaviour (the occurrence of $\mathrm{F}$ or $\mathrm{B}$ harmonic suffix alternants). In the case of antiharmony this is lexical variation: some $[\mathrm{N}]$ roots are antiharmonic $([\mathrm{N}] \mathrm{B}$, e.g. firr-to:l (* Jirrtø:l) 'grave-ABL'), others are not ([N]F, e.g. hi:r-tø:l ("hi:r-to:l) 'news-ABL'). For [ ...BN] roots, variation means vacillation: one and the same [..BN] root may get either a front or a back harmonic suffix alternant ([...BN]F\%B, e.g. fotel-ban or fotel-ben 'armchair-INEss'). The probability of vacillation obeys the Height Effect. It depends on the rank the $\mathrm{N}$ vowel has in the neutrality scale: the lower the rank, the more probable it is that variation occurs (and the higher the probability of the F suffix alternant is).

\subsection{Transparency and the Height Effect}

It can be seen in (1) above that the transparency of neutral vowels is gradient. $\mathbf{i}(\mathbf{:})$ are fully transparent in all lexical items, ${ }^{10}$ e: is fully transparent in most lexical items (ta:je:r-ban, *ta:je:r-ben 'plate-INESS') and variably transparent in some (arze:n-nal \% arze:n-nel 'arsenicINSTR'), and $\varepsilon$ tends to be variably transparent (fotel-ban or fotel-ben), but can be fully trans-

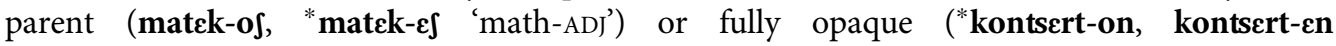
'concert-SUPERESS') in some lexical items. Furthermore, lexemes can differ in the degree of variation (the ratio of F/B suffix alternants) they manifest (and this is gradient, too). This means that while variation in transparency as manifested in vacillation is subject to the Height Effect, it also displays lexical variation. Transparency is not only conditioned by the identity of the neutral vowel, but also the lexical class of the stem it occurs in, (especially) for e: and $\varepsilon .^{11}$

\subsection{Transparency and the Count Effect}

There is another effect on the transparency of neutral vowels in addition to the Height Effect. The Count Effect (Ringen \& Kontra 1989; Hayes \& Cziráky Londe 2006; Hayes et al. 2009) is due to the distance between the harmonic trigger vowel and the suffixal target vowel: the longer the sequence of $\mathrm{N}$ vowels separating the trigger from the target is, the less transparent the string of $\mathrm{N}$ vowels is. ${ }^{12}$ The Count Effect manifests itself in vacillation [BNN]F/B: alibi-val \% alibi-vel 'alibi-INSTR'. It also interacts with the Height Effect: although $\mathbf{i}(:)$ are fully transparent, $\mathrm{N}+\mathbf{i}(:)$

\footnotetext{
${ }^{10}$ But see footnote 5 above.

11 "Familiar" [ . . Be:] words (native words, old loans, frequent recent loans, e.g. ta:je:r above) show no vacillation and get a back suffix alternant while "foreign" [ . . Be:] words (relatively recent loans such as arze:n) vacillate. Since all [...Be] words belong to the "foreign" lexical class, they tend to induce vacillation. Further lexical subclasses are also involved: $\varepsilon$ is fully transparent in "cultural" [ . .Be ] words, but tends to be opaque in "slangy" ones (especially when the suffix is vowel-initial), cf. Forró 2013; Rebrus \& Törkenczy 2019; Rebrus et al. 2020).

${ }^{12}$ This practically means exactly two $\mathrm{N}$ vowels. There are very few $\left[\mathrm{BNNN}^{+}\right]$roots and they behave in the same way as [BNN] roots, e.g. horribilis-tø:l/to:l 'horrible-ABL'. The scarceness of data does not permit further generalisation.
} 
strings are variably transparent (i.e. [BNi(:)] stems induce vacillation e.g. alibi-val \% alibi-vel). $\mathrm{N}^{+}$e: strings behave in the same way (e.g. klarine:t-tal \% klarine:t-tel 'clarinet-INSTR'). However, in spite of the variable transparency of $\varepsilon, \mathrm{N}^{+} \varepsilon$ strings are fully opaque and consequently [BNe] stems permit no vacillation and require a front harmonic suffix alternant, e.g. *mandiner-bo:l, mandiner-bø:l 'rebound-eLAT'. ${ }^{13}$ There is very little lexical variation associated with the Count Effect. [...BNN] roots are all recent loans and belong to the "foreign" lexical class, but a few are reclassified as "familiar" because of their high frequency. Thus in these stems the string of $\mathrm{N}$ vowels is fully (or highly) transparent and they show no (or very little) vacillation, e.g. a:prilifban, *a:prilif-ben 'April-INE; poziti:v-ak, ?" poziti:v-ek 'positive-PL'.

\subsection{Antiharmony and the Polysyllabic Split}

Antiharmony shows lexical variation, i.e. it is unpredictable which all-neutral root is antiharmonic and which one is not and thus roots of identical vocalic makeup can behave differently harmonically, e.g. firr-to:l 'grave-ABL' but hi:r-tø:l 'news-ABL, irt-ok 'annihilate-1SG.INDEF' but intعk 'wave-1SG.INDEF', he:j-as 'shell-ADJZ' but ke:j- $\varepsilon \int$ 'lust-ADJZ', etc. However, antiharmony is also subject to phonological constraints: (i) the Height Effect (cf. (1)): most antiharmonic roots have $\mathbf{i}(\mathrm{:})$, a few have e: and none has $\boldsymbol{\varepsilon},{ }^{14}$ and (ii) the Polysyllabic Split, a prosodic constraint that requires that antiharmonic root morphemes should be monosyllabic, e.g. kilintf-tø:l 'door handle-ABL' ("kilintf-to:l), vide:k-rø:l 'country-DEL' (*vide:k-ro:l). We summarise the Polysyllabic Split in (2) where a star marks the existence of a low number of exceptions.

(2) Antiharmony and the Polysyllabic Split

\begin{tabular}{|l|c|c|c|}
\hline Root vowel & $\mathrm{i}(\mathrm{:})$ & $\mathrm{e}:$ & $\varepsilon$ \\
\hline$[\mathrm{N}]$ & $+1-$ & $-\mid+$ & $-*$ \\
\hline$[\mathrm{NN}+]$ & \multicolumn{4}{|c|}{$-*$} \\
\hline
\end{tabular}

\section{HARMONIC UNIFORMITY}

When we compare the harmonic behaviour of non-vacillating monomorphemic [...BN] stems (e.g. kotfi 'car', ka:ve: 'coffee') with morphologically complex stems of harmonically identical relevant vocalic makeup whose $\mathrm{N}$ vowel is an invariant suffix (jog-i 'law-ADJZ, ha:z-e: 'house3SG.POSS'), we may conclude that front/back harmony (in this case, transparency) is independent of the morphological makeup of the stem since morphologically simplex and complex stems behave in the same way harmonically: ${ }^{15}$ e.g. kotji-ban 'car-INE', jog-i-ak 'law-ADJZ-PL'; ka:ve:-to:l

\footnotetext{
${ }^{13}$ The interaction of the Count Effect with the Height Effect manifests itself in a more nuanced way in the gradience/ probability of vacillation, which we abstract away from in this paper, cf. Rebrus \& Törkenczy (2016b) for details.

${ }^{14}$ There are a handful of exceptions: the bound root herv- (herv-ad, herv-ast 'wither'), one alternant of the root dere:k (derek-a, derek-uk etc. 'waist-3SG/3PL/... POSS') and some variably antiharmonic roots (of socially/stylistically restricted use) e.g. Svejts-ban 'Switzerland-INE', Spejz-ban 'pantry-INE'.

${ }^{15}$ Within the harmonic domain.
} 
'coffee-ABL', ha:z-e:-to:l 'house-POSS-ABL'. ${ }^{16}$ However, this simple relationship only holds under these specific conditions and the interaction between harmony and morphology is more intricate.

This intricacy is due to a morphological constraint on harmony in suffixed forms we will refer to as Harmonic Uniformity. Harmonic Uniformity is an output-output constraint, which holds between surface forms (see e.g. Benua 1995; Kenstowicz 2005). It requires that within the extended paradigm of a stem (which includes all singly or multiply suffixed forms with harmonically alternating suffixes whether inflectional or derivational, cf. Steriade 2000) harmonic behaviour must be consistent in that all the alternating suffixes occurring in the forms within the paradigm must have identical harmonic values (F, B or vacillating F/B). Harmonic Uniformity can be stated as (3) (cf. Rebrus \& Törkenczy 2016c; Rebrus et al. 2017):

\section{HARMONIC UNIFORMITY}

All the harmonic suffixes have identical harmonic values ( $\mathrm{F}, \mathrm{B}$ or $\mathrm{F} / \mathrm{B})$ within the paradigm of a stem.

On the one hand, this means that (i) any given alternating suffix must agree in its harmonic value with that of any other alternating suffix in any word form within the extended paradigm (this is the paradigmatic aspect of Harmonic Uniformity), so e.g. if bolt-ok, *bolt-عk, *bolt-øk 'shop-PL', then bolt-ban, * bolt-ben 'shop-INESS', and bolt-unk, *bolt-ynk 'shop-3PL.POss', etc. On the other hand, (ii) in any given form all the alternating suffixes must have identical harmonic values (this is the syntagmatic aspect of Harmonic Uniformity), e.g, bolt-ok-ban, *bolt-ek-ban, *bolt-ok-ben 'shop-PL-INESS', etc.

In the examples above, where the vowels of the stem unambiguously determine the harmonic behaviour of the alternating suffixes, Harmonic Uniformity applies trivially, i.e. in agreement with the phonological properties of the stem. However, there are more interesting cases when the vowels of the stem underdetermine its harmonic behaviour (cf. Section 2 above) and it is also suffixed with invariant suffixes whose vowel is neutral. Table (4) shows the ways in which Harmonic Uniformity works in these cases with harmonic and antiharmonic roots.

\subsection{Harmonic Uniformity and transparency}

(4) shows singly and multiply suffixed alternating and non-alternating harmonic (4a) and antiharmonic (4b) roots. In the formulae the abbreviations for natural classes of vowels are the following: F [-back], B [+back], N [-back, -round]. The first rows in (4ab) contain a nonalternating root (di:s 'ornament', hi:g 'thin'), the second and third rows alternating ones ("epenthetic" iker $\sim$ ikr- 'twin', pisok $\sim$ pisk- 'dirt' and "truncating"17 be:ke be:k- 'peace', be:na $\sim$ be:n- 'paralised'), and the last two rows contain bound roots (se:d- 'dizzy', Je:r- 'hurt', vif- 'scream', izg- 'excited').

\footnotetext{
${ }^{16}$ This is the reason why analyses of HVH usually assume that morphological complexity does not matter within the harmonic domain.

17 "Epenthetic" and "truncating" are just labels and not meant to suggest an analysis.
} 
(4) Harmonic Uniformity and root alternations

a. with harmonic roots

\begin{tabular}{|c|c|c|c|}
\hline root: [N(F)] & {$[N N] F$} & {$[\mathrm{~N}] \mathrm{F}$} & {$[[N] N] F$} \\
\hline di:s & - & di:s-yk & di:s-i:t-yyk \\
\hline iker $\sim$ ikr- & iker-tø:l & ikr-yk & - \\
\hline be:ke $\sim$ be:k- & be:ke:-tø:l & be:k-yl & be:k-i:t-yyk \\
\hline se:d- & - & se:d-yl & se:d-i:t-yyk \\
\hline se:r- & - & se:r-yl, se:r-t-ø: & - \\
\hline
\end{tabular}

b. with anti-harmonic roots

\begin{tabular}{|l|l|l|l|}
\hline root: $[\mathrm{N}(\mathrm{B})]$ & {$[\mathrm{NB}] \mathrm{B}$} & {$[\mathrm{N}] \mathrm{B}$} & {$[[\mathrm{N}] \mathrm{N}] \mathrm{B}$} \\
\hline hi:g & - & hi:g-ak & hig-i:t-unk \\
\hline pisok $\sim$ pisk- & pisok-ra & pisk-of & pisk-i:t-ok \\
\hline be:na $\sim$ be:n- & be:na-fa:g & be:n-ul & be:n-i:t-a: \\
\hline vif- & - & vif-ong & vif-i:t-ok \\
\hline izg- & - & izg-ul, izg-at & - \\
\hline
\end{tabular}

The last rows in both parts of (4) the singly suffixed forms of the harmonic and antiharmonic bound roots Je:r- and izg- show the paradigmatic application of Harmonic Uniformity: the former consistently takes the front suffix alternants (e.g. Se:r-yl 'become hurt') and the latter the back ones (izg-ul 'fret'). The doubly suffixed forms in the last column show the syntagmatic application of Harmonic Uniformity: the harmonic type of the root is preserved in the multiply suffixed forms even if there is an invariant $\mathrm{N}$ suffix between the root and the alternating suffix, which appears in its front alternant when the root is front harmonic and its back alternant when the root is antiharmonic (dis-itt-ve 'ornament-VERBZ-ADVZ', be:k-i:t-ynk 'peace-VERBZ-1PL', se:d-

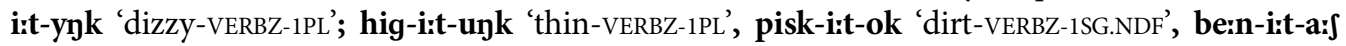
'paralised-VERBZ-NOMZ', vif-i:t-ok 'scream-VERBZ-1SG.NDF'). A comparison of the first and fourth rows shows that it makes no difference whether the root is free (di:s, hi:g) or bound (se:d-, vif-). The examples where the root appears in an alternant lacking the information (a vowel) that unambiguously determines harmony and is present in the other root alternant are especially interesting. "Epenthetic" stems (whose final syllable loses its vowel before a vowel-initial suffix, e.g. iker $\sim$ ikr-, pisok pisk-) and some vowel-final stems (whose final vowel is "truncated" before certain suffixes, e.g. be:ke $\sim$ be:k-, be:na $\sim$ be:n-) belong here. Harmonic Uniformity uniquely determines harmonic behaviour even in these cases: ikr-ek 'twin-PL' but pisk-os 'dirt-

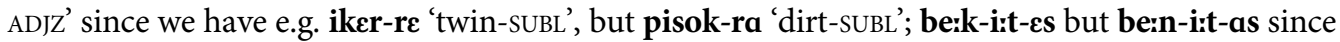
we have e.g. be:ke:-tø:l 'peace-ABL' but be:na-Ja:g 'paralised-NOMZ'. In such cases the phonological information missing from a specific form is available in the paradigm and accessible via Harmonic Uniformity. The identical harmonic behaviour of monomorphemic stems like e.g. radi:r 'rubber eraser' and morphologically complex ones like tan-itt 'teach' (both require back suffix 
alternants, e.g. radirr-oz 'rubber eraser-VERBZ', tan-i:t-ok 'teach-1SG.INDEF') might (mis)lead us to think (cf. e.g. Siptár \& Törkenczy 2000) that harmony is independent of morphological complexity and Harmonic Uniformity plays no role. Epenthetic and truncating stems provide independent evidence for Harmonic Uniformity.

Further evidence can be found when we examine cases when harmony based on phonological structure/makeup (including the Height Effect, the Count Effect and the Polysyllabic Split, cf. Section 2) is in conflict with Harmonic Uniformity. In these cases it is always Harmonic Uniformity that prevails.

Table (5) illustrates the conflict between Harmonic Uniformity and the Count Effect. ${ }^{18}$

(5) Harmonic Uniformity and transparency

\begin{tabular}{|c|c|c|c|c|}
\hline Stem type & $\begin{array}{l}\text { Harmonic Unifo } \\
\text { (morphology) }\end{array}$ & & & $\begin{array}{l}\text { Transparency } \\
\text { (phonology) }\end{array}$ \\
\hline I & II & III & & IV \\
\hline$[\mathrm{X}]_{\mu} \mathrm{Y}$ & {$[\mathrm{X}]_{\mu} \mathrm{Z}$} & {$\left[[\mathrm{X}]_{\mu} \mathrm{Y}\right] \mathrm{Z}$} & & {$[X Y] Z$} \\
\hline $\begin{array}{l}\text { a. }[B] B \\
\text { ha:Z-a }\end{array}$ & $\begin{array}{l}\text { ha:z-to:l } \\
\text { *ha:z-tø:l }\end{array}$ & $\begin{array}{l}\text { ha:z-a:-to:l } \\
\text { *ha:z-a:-tø:l }\end{array}$ & $=$ & $\begin{array}{l}\text { pa:ra:-to:I } \\
\text { *pa:ra:-tø:I }\end{array}$ \\
\hline $\begin{array}{l}\text { b. [B]N } \\
\text { ha:z-i }\end{array}$ & $\begin{array}{l}\text { ha:z-to:l } \\
* \text { ha:z-tø:l }\end{array}$ & $\begin{array}{l}\text { ha:z-i-to:l } \\
\text { *ha:z-i-tø:l }\end{array}$ & $=$ & $\begin{array}{l}\text { va:dli-to:l } \\
\text { *va:dli-tø:l }\end{array}$ \\
\hline $\begin{array}{c}\text { ci. [[B]N]N } \\
\text { ha:z-e:-i }\end{array}$ & $\begin{array}{l}\text { ha:z-to:l } \rightarrow \\
{ }^{*} \text { ha:z-tø:l }\end{array}$ & $\begin{array}{l}\text { ha:z-e:-i-to:l } \\
\text { *ha:z-e:-i-tø:l }\end{array}$ & $\begin{array}{l}= \\
\neq\end{array}$ & $\begin{array}{l}\text { aske:zij-to:l } \\
\text { aske:zif-tø:l }\end{array}$ \\
\hline $\begin{array}{l}\text { cii. [BN]N } \\
\text { madrid-i }\end{array}$ & $\begin{array}{l}\text { madrid-to:l } \rightarrow \\
{ }^{*} \text { madrid-tø:l }\end{array}$ & $\begin{array}{l}\text { madrid-i-to:I } \\
\text { * madrid-i-tø:I }\end{array}$ & $\begin{array}{l}= \\
\neq\end{array}$ & $\begin{array}{l}\text { alibi-to:l } \\
\text { alibi-tø:l }\end{array}$ \\
\hline $\begin{array}{l}\text { di. [BNN]N } \\
\text { martinik-i }\end{array}$ & $\begin{array}{l}\text { martinik-to:l } \\
\text { martinik-tø:l }\end{array}$ & $\begin{array}{l}\text { martinik-i-to:I } \\
\text { martinik-i-tø:l }\end{array}$ & $=$ & $\begin{array}{l}\text { horribilif-to:l } \\
\text { horribilif-tø:l }\end{array}$ \\
\hline $\begin{array}{r}\text { dii. }[B \varepsilon] N \\
\text { haver-i }\end{array}$ & $\begin{array}{l}\text { haver-to:I } \\
\text { haver-tø:I }\end{array}$ & $\begin{array}{l}\text { haver-i-to:l } \\
\text { haver-i-tø:l }\end{array}$ & $=$ & $\begin{array}{l}\text { bakelit-to:I } \\
\text { bakelit-tø:I }\end{array}$ \\
\hline
\end{tabular}

In (5) we examine the doubly suffixed forms $\left[[\mathrm{X}]_{\mu} \mathrm{Y}\right] \mathrm{Z}$ in column III whose second suffix $\mathrm{Z}$ is a harmonically alternating one (ablative -to:l tø:l) by comparing them to the forms in the other columns. Column I contains suffixed forms that are identical to those in III minus the last alternating suffix (ablative -to:l $\sim$ tø:l). Column II has singly suffixed forms of the roots $[\mathrm{X}]_{\mu}$ in columns I and III where the suffix is a harmonically alternating one (the ablative): $[\mathrm{X}]_{\mu} \mathrm{Z}$. Column IV shows forms whose vocalic pattern preceding the final suffix is the same as the corresponding forms in the first column but their morphological structure is different in that they are monomorphemic stems suffixed by a single harmonically alternating suffix (the

\footnotetext{
${ }^{18}$ Glosses: ha:z 'house', ha:z-a 'house-3SG.POSS', ha:z-a:-to:l 'house-3SG.POSS-ABL, ha:z-i 'house-ADJZ', ha:z-i-to:l 'house-ADJZABL', ha:Z-e:-i 'house-POSS-PL', ha:z-e:-i-to:l 'house-POSS-PL-ABL'; madrid 'Madrid', madrid-i 'Madrid-ADJZ', madrid-i-to:l 'Madrid-ADJZ-ABL'; martinik 'Martinique', martinik-i 'Martinique-ADJZ', martinik-i-to:l/-tø:l 'Martinique-ADJZ-ABL'; haver 'mate', haver-i 'mate-ADJZ', haver-i-to:l/-tø:l 'mate-ADJZ-ABL'; pa:ra 'mist'; va:dli 'calf (leg)'; aske:zif 'asceticism'; alibi 'alibi'; horribilis 'horrible'; bakelit 'Bakelite'.
} 
ablative): $[\mathrm{XY}] \mathrm{Z}$. The equals sign $(=)$ means that phonological harmony and Harmonic Uniformity are not in conflict and the not equal sign $(\neq)$ indicates that they are.

(5a) shows that if the suffixes of a multiply suffixed stem ([[X]Y]Z) are harmonically alternating ones (Y, Z), then morphological structure makes no difference. Harmonic Uniformity and harmony both exclude the disharmonic form: *ha:z-a:-tø:l violates Harmonic Uniformity (cf. ha:zto:l) and phonological harmony too (compare * pa:ra:-tø:l). We can see the same in (5b): the form in column III is a doubly suffixed back harmonic root whose first suffix has the N vowel $\mathbf{i}$ and is invariant (the adjective-forming suffix -i) and the second one is harmonically alternating (ablative -to:l tø:l). Again, the difference in morphological structure does not matter: ungrammatical *ha:zi-tø:l is not supported by Harmonic Uniformity (since the paradigm of ha:z does has no forms with a front alternant of a harmonically alternating suffix, e.g. *ha:z-tø:l, see column II) and is also excluded by phonological harmony (since the N vowel $\mathbf{i}$ is fully transparent; compare *va:dli-tø:l, see column IV). Thus, in (5ab) we can see cases where Harmonic Uniformity and phonological harmony both exclude the same form (suffix alternant), i.e. they are not in conflict. In (5di, dii) we can see similar cases in which they are not in conflict, with the difference that Harmonic Uniformity and phonological harmony both support both suffix alternants (i.e. vacillation, forms with either harmonic suffix alternant). The multiply suffixed forms in column III of (5di, dii) which have the same morphological structure/suffixes as those in (5b) vacillate (martinik-i-to:l/tø:l, haver-ito:l/tø:l) - this is supported by Harmonic Uniformity (since the other harmonically suffixed members of their paradigm vacillate too, e.g. martinik-to:l/tø:l, haver-to:l/tø:l, see column II) and is permitted by phonological harmony (since the Count Effect requires vacillation in stems of this vocalic makeup anyway, e.g. horribilif-to:l/tø:l, bakelit-to:l/tø:l, see column IV). Thus, since Harmonic Uniformity and phonological harmony predict the same result in these cases, it would be enough to refer to only one of them to capture harmonic behaviour.

However, the interesting cases appear in (5ci, cii) where Harmonic Uniformity and phonological harmony conflict. In (5ci) we can see a multiply suffixed form where the root is a backharmonic one followed by two invariable suffixes whose vowel is neutral (anaphoric possessive -e: plural -i) and a harmonically alternating suffix (ablative -to:l $\sim$ tø:l). Since the paradigm of the root does not have forms with a front alternant of a harmonically alternating suffix (e.g. *ha:z-tø:l, see column II), Harmonic Uniformity does not support the multiply suffixed form with the front alternant of the ablative suffix. Therefore, *ha:z-e:-i-tø:l is ungrammatical even though harmony predicts vacillation because of the Count Effect as can be seen in the form in column IV aske:zifto:l/tø:l, which has the same vocalic makeup. In (5cii) we show a multiply suffixed form with a single invariable suffix whose vowel is neutral (adjective-forming -i) followed by a harmonically alternating suffix (ablative -to:l tø:l). The difference from ( $5 \mathrm{ci}$ ) is that this time the (single) invariable suffix is attached to a mixed root whose second vowel is $\mathbf{i}$ ([ . . Bi ] madrid). The paradigm of madrid does not contain forms with a back alternant of a harmonically alternating suffix (since $\mathbf{i}$ is fully transparent, e.g. * madrid-tø:l in column II), therefore Harmonic Uniformity does not support the form * madrid-i-tø:l, which is ungrammatical. Accordingly, there is no vacillation in spite of the fact that harmony predicts it because of the Count Effect (compare alibi-to:l/tø:l in column IV).

\subsection{Harmonic Uniformity and antiharmony}

In this section we examine a further instance of this relationship, this time related to antiharmony or more specifically the Polysyllabic Split, the phonological constraint on lexical variation in 
antiharmony (see 2.3) which restricts antiharmony to monosyllabic stems. This can be seen in (6) below. The forms in $(6 \mathrm{abc})$ have the same morphological structure as those in the corresponding rows of (5abc) and the columns (6 I, II, III, IV) correspond to the respective columns of (5). The only difference is that the root hi:d we focus on in (6) is antiharmonic. Again, the not equal sign $(\neq)$ indicates conflict between phonological harmony and Harmonic Uniformity.

(6) Harmonic Uniformity and antiharmonic stems ${ }^{19}$

\begin{tabular}{|c|c|c|c|c|}
\hline Stem type & $\begin{array}{l}\text { Harmonic U } \\
\text { (morpholog }\end{array}$ & rmity & & $\begin{array}{l}\text { Polysyllabic Split } \\
\text { (phonology) }\end{array}$ \\
\hline I & II & III & & IV \\
\hline$[\mathrm{X}]_{\mu} \mathrm{Y}$ & {$[\mathrm{X}]_{\mu} \mathrm{Z}$} & {$\left[[\mathrm{X}]_{\mu} \mathrm{Y}\right] \mathrm{Z}$} & & {$[\mathrm{XY}] \mathrm{Z}$} \\
\hline $\begin{array}{l}\text { a. [N]B } \\
\text { hi:d-ja }\end{array}$ & $\begin{array}{l}\text { hi:d-to:l } \\
\text { *hi:d-tø:l }\end{array}$ & $\begin{array}{l}\text { hi:d-ja:-to:l } \\
\text { *hi:d-ja:-tø:l }\end{array}$ & $=$ & $\begin{array}{l}\text { vira:g-to:I } \\
\text { *vira:g-tø:l }\end{array}$ \\
\hline $\begin{array}{l}\text { b. [N]N } \\
\text { hi:d-e: }\end{array}$ & $\begin{array}{l}\text { hi:d-to:l } \rightarrow \\
{ }^{*} \text { hi:d-tø:l }\end{array}$ & $\begin{array}{l}\text { hi:d-e:-to:l } \\
{ }^{*} \text { hi:d-e:-tø:I }\end{array}$ & $\neq$ & $\begin{array}{l}\text { *bide:-to:I } \\
\text { bide:-tø:l }\end{array}$ \\
\hline $\begin{array}{l}\text { c. }[[N] N] N \\
\text { hi:d-e:-i }\end{array}$ & $\begin{array}{l}\text { hi:d-to:l } \rightarrow \\
{ }^{*} \text { hi:d-tø:l }\end{array}$ & $\begin{array}{l}\text { hi:d-e:-i-to:l } \\
\text { *hi:d-e:-i-tø:l }\end{array}$ & $\neq$ & $\begin{array}{l}\text { *sinte:zif-to:I } \\
\text { sinte:zif-tø:I }\end{array}$ \\
\hline
\end{tabular}

In (6a) column I the last suffix (as well as the first) of the the doubly suffixed form must occur in its back alternant (hi:d-ja:-to:l) because the paradigm of the root hi:d only has forms with the back alternants of harmonising suffixes since it is antiharmonic (e.g. hi:d-to:l, *hi:d-tø:l, see column II). This is exactly what phonological harmony requires for a singly suffixed form with the same vocalic structure (compare vira:g-to:l, *vira:g-tø:l, see column IV). However, Harmonic Uniformity and phonological harmony are in conflict when a harmonically alternating suffix is attached to a stem that consists of an antiharmonic root followed by one (6b) or more than one (6c) invariant neutral-vowel suffix. In these cases the harmonic suffix must occur in its back alternant (hi:d-e:-to:l, hi:d-e:-i-to:l, see column III) due to Harmonic Uniformity (e.g. hi:dto:l, *hi:d-tø:l, see column II) although phonological harmony would require a front alternant (compare *bide:-to:l, bide:-tø:l, * sinte:zif-to:l, sinte:zif-tø:l, see column IV) where the examples cannot be antiharmonic because of the Polysyllabic Split (cf. Section 2.3).

\subsection{Interim summary}

To sum up, in most of the cases the effect of Harmonic Uniformity follows from (or is in agreement with) the phonological constraints on vowel harmony and the behaviour of neutral vowels ((5abd), (6a)). However, in some cases (and these always involve invariant suffixes with neutral vowels) harmony and Harmonic Uniformity are in conflict and then it is always the latter that wins out, ${ }^{20}$ i.e. the morphological structure via the paradigmatic constraint overrides

\footnotetext{
${ }^{19}$ Glosses: hi:d 'bridge', hi:d-ja 'bridge-3SG.POSs', hi:d-ja:-to:l 'bridge-3SG.POSS-ABL', hi:d-e: 'bridge-POSs', hi:d-e:-to:l 'bridge-POSSABL', hi:d-e:-i 'bridge-POSS-PL', hi:d-e:-i-to:l 'bridge-POSS-PL-ABL'; vira:g 'flower'; bide: 'bidet'; sinte:zis 'synthesis'.

${ }^{20}$ However, see the discussion about the special case of invariant back suffixes in Section 4.1, tableau (8iv).
} 
the phonological constraints on harmony and neutral vowels (Rebrus \& Törkenczy 2016c). In the case of transparency this reduces variation (cf. $(5 c)$ ) by banning vacillation (madrid-i-to:l/ *-tø:l although alibi-to:l/-tø:l). In the case of antiharmony, when Harmonic Uniformity overrides the Polysyllabic Split (cf. (6bc), lexical variation increases since antiharmony extends over polysyllabic stems too (hi:d-e:-to:l although bide:-tø:l), cf. Rebrus \& Törkenczy (2017a).

Harmonic Uniformity applies at morpheme level and not at the level of morphs. This means that the harmonic behaviour of a root morpheme is consistent, i.e. every cell of the extended paradigm of a given root must realise identical harmonic values (the forms in every cell must be all front harmonic (F), or back harmonic (B) or every cell must contain both F and B forms (F/ B)). This, however, does not imply that every possible F, B or F/B (vacillating) form (exponent) must be present in every cell. This distinction becomes crucial in the case of vacillation. For instance, harmonic vacillation in a cell may be realised in more than one way with the $-\mathbf{j a} \sim \mathbf{j} \boldsymbol{\varepsilon} \sim \mathbf{q} \sim \boldsymbol{\varepsilon}$ 3SG.POSS suffix allomorphs in the possessive forms of vacillating stems (logically, there are 9 possible ways). The stems hotel 'hotel', notes 'notebook' and haver are vacillating stems (cf. hotel-to:l/tø:l 'hotel-ABL', notes-to:l/tø:l 'notebook-ABL' and haver-to:l/tø:l), therefore they must have both $\mathrm{F}$ and $\mathrm{B}$ forms in every cell of their paradigms in accordance with Harmonic Uniformity. However, this does not mean that they have to make use of all the 3SG.POSs suffix allomorphs $(-\mathbf{j a} \sim \mathbf{j} \boldsymbol{\varepsilon} \sim \mathbf{a} \sim \boldsymbol{\varepsilon})$ to realise vacillation in the relevant cells of their paradigms. hotel-ja/

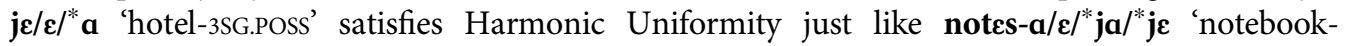
3SG.POSS' or haver-ja/je/*a/ $/^{*} \boldsymbol{\varepsilon}$ 'mate-3SG.POSS' since the 3SG.POSS cells of their paradigms contain both forms with front suffix alternants and forms with back suffix alternants just like the other cells of their paradigms. It makes no difference for Harmonic Uniformity that in the first case this is realised by three forms as opposed to just two in the second and third cases.

There are systematic violations of Harmonic Uniformity in backness harmony (cf. Rebrus \& Törkenczy 2019) including the (very few) invariant suffixes with harmonic (back) vowels (e.g. temporal -kor and verbal suffixes -a:l, -ol) and the behaviour of forms with certain invariant diminutive suffixes. We will discuss these in Section $4 .^{21}$

\section{ANALYSIS}

In this section we present an analysis of the interaction between front/back harmony and Harmonic Uniformity. It is an Optimality Theory (OT) analysis in that it evaluates competing candidates based on how they fare on a potentially ranked set of constraints (e.g. Prince \& Smolensky 1993/2004), but it is different from canonical OT in important respects. The candidate set is not an infinite number of forms generated by an omnipotent Generator, but rather actually occurring surface forms or potential forms resulting from the combination of available suffix allomorphs with the relevant stems. The constraints that evaluate the competing forms are not assumed to be part of UG but are conceived of as language-specific generalisations over (sets of) surface forms that the speakers have memorised (cf. Archangeli \& Pulleyblank 2015a,b; 2017; Rebrus et al. 2017).

The "composite" tableaux below follow the conventions and notations usual in Optimality Theory except that (i) the first cell of the first column does not contain an underlying

\footnotetext{
${ }^{21}$ Harmonic Uniformity does not apply in rounding harmony (for a detailed discussion cf. Rebrus \& Törkenczy 2019).
} 
form, ${ }^{22}$ but a morphological/morphosyntactic description of the forms considered, (ii) each tableau is a composite of several parallel tableaux (each row is one) so the competing candidates appear within each row (i.e. the rows labelled alphabetically are not competing candidates), (iii) as is usual, a star denotes a violation but for ease of reference we have also indicated what exactly the violation is: (a) a string in violation of a constraint appears in parentheses next to the star (i.e. * (xy) means that the string xy violates the relevant constraint), (b) in the case of a paradigm uniformity constraint a description of grammatical harmonic behaviour (a formula) appears next to the star in curly brackets (i.e. ${ }^{*}\{\operatorname{Root}+\mathrm{B}\}$ means that the paradigm of the Root only contains listed forms with back alternants of harmonic suffixes and the constraint is violated because the candidate does not have a back suffix alternant). Starred candidates are ungrammatical, grammatical ("winning") candidates are emboldened. In the tableaux we omit length marks in formulae to save space.

\subsection{Harmonic and neutral vowels}

(7i) shows the simple case of front/back harmony applying with harmonic stems when combined with a harmonically alternating suffix (here, the suffix -uk/-yk '3PL'). We distinguish two versions of the harmony constraint in accordance with the difference in the tolerance/frequency of disharmony between harmonic vs. neutral vowels (see Section 2). HAR-F penalises strong disharmony (disharmony with harmonic vowels: ${ }^{*} \mathrm{FB},{ }^{*} \mathrm{BF}$ ) and HAR-N penalises weak disharmony (disharmony involving neutral vowels: $\left.{ }^{*} \mathrm{NB},{ }^{*} \mathrm{BN}\right)$. Technically, we will not consider $\varepsilon$ as a member of the harmonic $(\mathrm{F})$ and the neutral $(\mathrm{N})$ set: because of its intermediate harmonicity/neutrality it will have a special status and constraints specific to it. ${ }^{23}$ As can be seen in (7i:a) and (7i:b) HAR-N selects the grammatical candidates (ka:r-uk 'damage-3PL', bø:r-yk 'skin3PL'). HAR-F is ranked above HAR-N. The latter plays no role in the selection of the grammatical candidates in (7i:ab), but it is necessary as can be seen in (7i:c) where it selects the grammatical candidate (hi:r-yk 'news-3PL') in the case of a harmonic all-neutral root (e.g. hi:r).

$$
\text { Harmony (simple cases) }-\mathrm{F}=\{\mathrm{y}, \mathrm{y:}, \emptyset, \varnothing:\}, N=\{\mathrm{i}, \mathrm{i}, \mathrm{e}:\}
$$

\begin{tabular}{|c|c|c|}
\hline$R O O T+3 P L$ & $\begin{array}{c}\text { HAR-F } \\
\left({ }^{*} \mathbf{F B}, * \mathbf{B F}\right)\end{array}$ & $\begin{array}{c}\text { HAR-N } \\
\left(*^{*} \mathrm{NB},{ }^{*} \mathrm{BN}\right)\end{array}$ \\
\hline $\begin{array}{r}\text { a. ka:r-uk } \\
\text { *ka:r-yk } \\
\end{array}$ & $*($ ay) & \\
\hline $\begin{array}{c}\text { b. *bø:r-uk } \\
\text { bø:r-yk }\end{array}$ & $*(\varnothing \mathrm{u})$ & \\
\hline $\begin{array}{c}\text { c. }{ }^{* h i r r-u k} \\
\text { hi:r-yk }\end{array}$ & & $*(\mathrm{iu})$ \\
\hline
\end{tabular}

(7ii) compares the behaviour of all-neutral harmonic and antiharmonic roots (the latter can only contain a neutral vowel, cf. (1)) when combined with a harmonically alternating suffix. This is

\footnotetext{
${ }^{22}$ The analysis does not refer to underlying forms.

${ }^{23}$ See Section 4.2. and figure (14).
} 
the first point in the analysis of harmony where Harmonic Uniformity (cf. (3)) plays a role. HARUNI is a paradigmatic uniformity constraint which compares the forms being evaluated to all the harmonically suffixed forms in the extended paradigm of the relevant stem with respect to their harmonic behaviour F, B, B/F (which may be different depending on the stem). These other forms are assumed to be listed, stored by the speaker (Steriade 1999; 2008) and used as a reference set to predict the grammatical realisation (candidate) of the form examined. ${ }^{24}$ The stem hi:r in (7ii:a) is a harmonic one (cf. (7i)), Ji:r 'grave' in (7ii:b) is antiharmonic and the allneutral stem in (7ii:c) is one whose paradigm is unknown (it has no other stored forms, e.g. it is a recent loan (e.g. hi:v 'HIV'), a foreign name (e.g. grints 'Grinch') or a nonce word (e.g. fint), etc.).

(7ii) Neutral vowels in harmonic and antiharmonic roots

\begin{tabular}{|c|c|c|c|}
\hline$R O O T+3 P L$ & $\begin{array}{c}\text { HAR-F } \\
\left({ }^{*} \mathrm{FB}, * \mathrm{BF}\right)\end{array}$ & HARUNI & $\begin{array}{c}\text { HAR-N } \\
(* \mathrm{NB}, * \mathrm{BN})\end{array}$ \\
\hline $\begin{array}{r}\text { a. } \begin{array}{c}\text { hi:r-uk } \\
\text { hi:r-yk }\end{array} \\
\end{array}$ & & $*\{$ hi:r $+\mathbf{F}\}$ & $*(\mathrm{iu})$ \\
\hline b. $\begin{array}{l}\text { iirr-uk } \\
* \int \mathrm{i}: r-y k\end{array}$ & & $*\left\{\int \mathrm{i}: \mathbf{r}+\mathbf{B}\right\}$ & $*(\mathrm{iu})$ \\
\hline $\begin{array}{c}\text { c. }{ }^{*} \mathrm{~N} \text {-uk } \\
\mathrm{N} \text {-yk }\end{array}$ & & & $*(\mathrm{iu})$ \\
\hline
\end{tabular}

Since these stems only contain neutral vowels (recall that antiharmonic stems never have harmonic vowels), HAR-F plays no role in selecting the grammatical candidates. Phonology (HAR-N) and morphology (HARUNI) overlap in (7ii:a): they both advocate (and exclude) the same candidates, but they are in conflict in the case of antiharmonic stems, when HARUNI determines harmonic behaviour (this is expressed by ranking HARUNI above HAR-N). As can be seen phonological shape partially underdetermines harmony (7ii:a) vs. (7ii:b). Indeterminacy is not absolute because HAR-N does play a crucial role if HARUNI is inactive because there are no stored forms in the paradigm (7ii:c). This explains why antiharmony is not productive and all-neutral loans and nonce words take the front alternants of harmonically alternating suffixes.

We have pointed out that antiharmony is systematically restricted to roots that contain neutral vowels only. (7iii) is how this generalisation is implemented in the present analysis, i.e. it explains why this type of lexical variation cannot occur with roots with a harmonic vowel. In the first column of (7iii:ab) F and B are roots whose last vowel is front and back harmonic, respectively. We can see that HAR-F excludes antiharmonic behaviour by selecting the candidates that are not involved in strong disharmony. Again, this shows that even though phonological harmony and morphology may overlap in some cases (e.g. (7ii:a)), phonology can decide when they are in conflict (e.g. (7iii:ab)). (7iii) assumes that other forms of the roots examined are known (stored), hence the violations of HARUNI. Note, however, that the analysis works in the

\footnotetext{
${ }^{24}$ One can think of this as a version of the "Paradigm Cell Filling Problem", cf. Ackerman et al. (2009), Finkel \& Stump (2009).
} 
same way even if we assume that the roots have just been borrowed or are nonce words since paradigm uniformity (morphology) is recessive in this case and therefore it makes no difference if HARUNI is violated or not.

(7iii) The impossibility of non-neutral vowels in antiharmonic roots

\begin{tabular}{|c|c|c|c|}
\hline$R O O T+3 P L$ & $\begin{array}{c}\text { HAR-F } \\
\left({ }^{*} \mathrm{FB},{ }^{*} \mathrm{BF}\right)\end{array}$ & HARUNI & $\begin{array}{c}\text { HAR-N } \\
\left(* \mathrm{NB},{ }^{*} \mathrm{BN}\right)\end{array}$ \\
\hline $\begin{array}{r}* \text { a. F-uk } \\
* \mathrm{~F}-\mathrm{yk} \\
\end{array}$ & $*(\mathrm{Fu})$ & $*\{\mathrm{~F}+\mathrm{B}\}$ & \\
\hline 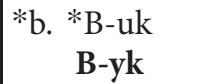 & *(By) & $*\{\mathrm{~B}+\mathrm{F}\}$ & \\
\hline
\end{tabular}

It is a curious characteristic of Hungarian front/back harmony that some neutral vowels can alternate harmonically: ${ }^{25}$ e: systematically, ${ }^{26}$ and even $\mathbf{i}$ in suppletive -ja $\sim \mathbf{i}$ 'SG3.DEF'. We can see this in (8i) with the adessive suffix -na:l ne:l when it is attached to stem whose trigger vowel is front harmonic ø:z 'roe deer' (8i:a), back harmonic ha:z 'house' (8i:b) and neutral ke:z 'hand' (8i:c).

The strongly disharmonic form in (8i:a) violates HAR-F (and the grammatical form ø:z-ne:l is selected). (8ii:bc) provide further proof for the constraint HAR-N: although the highly ranked HAR-F is inactive when the phonetically front alternant of a harmonic suffix (and/or the root) has a neutral vowel HAR-N selects the fully harmonic grammatical forms by excluding the weakly disharmonic ones ("ha:z-ne:l, "ke:z-na:l).

(8i) Neutral vowels in harmonically alternating suffixes

\begin{tabular}{|c|c|c|}
\hline$R O O T+A D E$ & $\begin{array}{c}\text { HAR-F } \\
\left({ }^{*} \mathbf{F B},{ }^{*} \mathbf{B F}\right)\end{array}$ & $\begin{array}{c}\text { HAR-N } \\
(* \mathrm{NB}, * \mathrm{BN})\end{array}$ \\
\hline $\begin{array}{c}\text { a. }{ }^{*} \text { ø:z-na:l } \\
\text { ø:z-ne:l }\end{array}$ & $*(\varnothing \mathrm{a})$ & \\
\hline $\begin{array}{l}\text { b. ha:z-na:l } \\
\text { *ha:z-ne:l }\end{array}$ & & $*(\mathrm{ae})$ \\
\hline 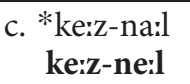 & & $*(\mathrm{ea})$ \\
\hline
\end{tabular}

(8ii) introduces a new uniformity constraint, suffix uniformity SFXUNI. Since we can refer to the extended paradigms of stems, i.e. a set of forms with various suffixes of the same stem, it

\footnotetext{
${ }^{25}$ Thus, neutrality cannot be derived from unpairedness (contra the usual assumption about neutrality, e.g. Hulst \& van de Weijer 1995).

${ }^{26}$ The vowel $\varepsilon$ also alternates harmonically in several suffixes. Recall that technically it is neither an $\mathrm{F}$ vowel nor an $\mathrm{N}$ in the analysis we are developing but has constraints specific to it.
} 
makes sense to refer to the paradigms of suffixes (Rebrus \& Törkenczy 2005; 2008), i.e. a set of forms that share the same suffix. HARUNI requires that the forms within a stem paradigm must be harmonically uniform (F, B, F/B) - similarly SFXUNI requires that the forms within a suffix paradigm must be harmonically consistent (F, B, F/B) and contain one of the suffix alternants. This makes it possible to distinguish harmonically alternating suffixes form invariant ones. The suffix paradigm of an alternating suffix contains forms with the front alternant and also the back alternant of the suffix, e.g. adessive $\{\text {-na:l, -ne: }\}^{27}$ while the suffix paradigm of an invariant suffix only has forms with a single suffix alternant, e.g. causalis \{-e:rt\}. Just like HARUNI, SFXUNi compares the forms evaluated to the listed forms, in this case the memorised forms of the suffix paradigm. (8ii) shows the analysis of invariant suffixes with harmonic stems. Recall that, systematically, invariant suffixes have neutral vowels (i, i:, e:) and not harmonic ones. This means that SFXUNI must be ranked above HAR-N and below HAR-F. Given this ordering we get the correct results. The strongly disharmonic hypothetical form in (8ii:a) is excluded by the highly ranked phonological constraint (as well as SFxUNI, redundantly). In (8ii), however, SFxUni plays an active role by excluding the fully harmonic hypothetical form *ha:z-a:rt (since all the listed/memorised forms in the suffix paradigm of CAU have $\{$-e:rt $\}$ ) and thus the weakly disharmonic form ha:z-e:rt is selected.

(8ii) Neutral vowel in harmonically invariant suffixes

\begin{tabular}{|c|c|c|c|}
\hline ROOT+CAU & $\begin{array}{c}\text { HAR-F } \\
\left({ }^{*} \mathbf{F B}, * \mathbf{B F}\right)\end{array}$ & SFXUNI & $\begin{array}{c}\text { HAR-N } \\
(* \mathbf{N B}, * \mathbf{B N})\end{array}$ \\
\hline $\begin{array}{c}\text { a. } * \text { ø:z-a:rt } \\
\text { Ø:z-e:rt }\end{array}$ & $*(\varnothing \mathrm{a})$ & $*\{$-e:rt $\}$ & \\
\hline $\begin{array}{c}\text { b. }{ }^{*} \text { ha:z-a:rt } \\
\text { ha:z-e:rt }\end{array}$ & & $*\{$-e:rt $\}$ & $*(\mathrm{ae})$ \\
\hline
\end{tabular}

SFXUni overrides HARUNI when in conflict as can be seen in (8iii) showing what happens when invariant -e:rt combines with an antiharmonic root (hi:r (8iii:a) is a harmonic root and fi:r (8iii:b) is an antiharmonic one). SFXUNI must rank higher than HARUNI since antiharmony cannot "make" an invariant suffix alternate because there is no form with a back suffix alternant in the suffix paradigm of the causative \{-errt\}, see (8iii:b). There is no conflict between SFXUNI and HARUNI when the stem is a harmonic one with an $\mathrm{N}$ vowel, see (8iii:a). Note that SFXUNI does not decide between similar candidates when the suffix is a harmonically alternating one since both candidates $(F, B)$ would satisfy it because the suffix paradigm of the alternating suffix would contain forms with the front alternant and the back alternant, too.

\footnotetext{
${ }^{27}$ An additional advantage of this approach is that it also makes it possible to treat phonologically conditioned suppletive suffix alternation (e.g. SG3 definite $\{$-ja, -i $\}$ conditioned by harmony: lop-ja 'steal-3SG.DEF', køp-i 'spit-3SG.DEF') on a par with non-suppletive harmony-conditioned alternations such as $\{-\mathbf{n a : l ,}$-ne:l $\}$.
} 
(8iii) Interaction of antiharmony and suffix invariance

\begin{tabular}{|c|c|c|c|c|}
\hline$R O O T+C A U$ & $\begin{array}{c}\text { HAR-F } \\
\left({ }^{*} \mathrm{FB},{ }^{*} \mathrm{BF}\right)\end{array}$ & SFXUNI & HARUNI & $\begin{array}{c}\text { HAR-N } \\
\left({ }^{*} \mathrm{NB},{ }^{*} \mathrm{BN}\right)\end{array}$ \\
\hline $\begin{array}{r}\text { a. } \begin{array}{c}* \text { hi:r-a:rt } \\
\text { hi:r-e:rt }\end{array}\end{array}$ & & $*\{$-e:rt $\}$ & $*\{$ hi:r $+\mathbf{F}\}$ & $*($ ia $)$ \\
\hline 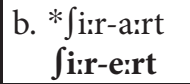 & & $*\{$-e:rt $\}$ & $*\left\{\int \mathrm{i}: \mathrm{r}+\mathbf{B}\right\}$ & $*(\mathrm{ia})$ \\
\hline
\end{tabular}

SFXUNI also makes it possible to account for invariant suffixes which have harmonic vowels. This occurs extremely rarely in Hungarian and only with back vowels (e.g. temporal \{-kor $\}$ øtkor '5-TEMP', hat-kor '6-TEMP'). Invariant suffixes with front vowels $(\{-F\})$ do not occur. This distribution can be accounted for if we split the hitherto symmetrical HAR-F into two asymmetrical constraints: $\mathrm{HAR}-\mathrm{F}_{\mathrm{R}}$ which bans strong disharmony with an $\mathrm{F}$ vowel on the right $\left({ }^{*} \mathrm{BF}\right)$ and HAR- $\mathrm{F}_{\mathrm{L}}$ which bans strong disharmony with an $\mathrm{F}$ vowel on the left $\left({ }^{*} \mathrm{FB}\right) .{ }^{28} \mathrm{We}$ get the right results if HAR- $F_{R}$ ranks higher than $H A R-F_{L}$ and SFXUNI is ordered in between the two constraints. This is shown in (8iv) where the SFXUNI overrides the effect of the two lower ranking harmony constraints which penalise (a) strong disharmony with an F vowel on the left and (b) weak disharmony, thus the grammatical forms øt-kor and he:t-kor are selected even though they violate these constraints but satisfy SFXUNI. The fully harmonic grammatical form hat-kor (8ivc) wins since it does not violate any of the harmony constraints and the hypothetical candidate *hat-kør fails on the highest ranking HAR-F $\mathrm{R}_{\mathrm{R}}$ (and redundantly on SFXUNI, too).

(8iv) Rare instance of back vowel in harmonically invariant suffixes

\begin{tabular}{|c|c|c|c|c|}
\hline ROOT+TEMP & $\begin{array}{c}\text { HAR-F } \\
\left({ }^{*} \mathrm{BF}\right)\end{array}$ & SFXUNI & $\begin{array}{c}\text { HAR }-F_{L} \\
\left({ }^{*} \mathrm{FB}\right)\end{array}$ & $\begin{array}{c}\mathrm{HAR} \mathrm{N}_{\mathrm{L}} \\
\left({ }^{*} \mathrm{NB}\right)\end{array}$ \\
\hline $\begin{array}{l}\text { a. øt-kor } \\
*_{\emptyset t-k ø r}\end{array}$ & & $*\{$-kor $\}$ & $*(\varnothing о)$ & \\
\hline $\begin{array}{l}\text { b. he:t-kor } \\
* \text { he:t-kør }\end{array}$ & & $*\{$-kor $\}$ & & $*(\mathrm{eo})$ \\
\hline $\begin{array}{l}\text { c. ha:t-kor } \\
\text { *hat-kør }\end{array}$ & $*(\mathrm{a} \emptyset)$ & $*\{$-kor $\}$ & & \\
\hline
\end{tabular}

(8v) shows that the ranking in (8iv) accounts for the fact that there are no invariant suffixes with front harmonic vowels. The suffix paradigm of a hypothetical suffix of this kind would only contain forms with a front harmonic suffix $\{-\mathrm{F}\}$. Therefore, it would have a front harmonic suffix after front harmonic stems (øt ' 5 ', (8va)) and back harmonic stems (hat ' 6 ', (8vb)) thereby

\footnotetext{
${ }^{28}$ Similarly, HAR-N is split into asymmetrical HAR- $\mathrm{N}_{\mathrm{R}}\left({ }^{*} \mathrm{BN}\right)$ and $\mathrm{HAR}_{\mathrm{A}} \mathrm{N}_{\mathrm{L}}\left({ }^{*} \mathrm{NB}\right)$. In the following analysis we focus on the latter, for the former, see $(8 \mathrm{i}, \mathrm{ii})$.
} 
satisfying SFXUNI. This, however, is only possible if the root is front harmonic (øt-F (8va)) and not when it is back harmonic (hat-F (8vb) since a form with a front harmonic suffix alternant after a back harmonic stem would violate the highest ranking constraint $\mathrm{HAR}-\mathrm{F}_{\mathrm{R}}$ and therefore the competing ungrammatical candidate ( ${ }^{*}$ hat-B) would win, which means that the suffix does alternate $(-\mathrm{F} \sim-\mathrm{B})$ and is not invariant.

(8v) The impossibility of front non-neutral vowels in invariant suffixes

\begin{tabular}{|c|c|c|c|c|}
\hline$R O O T+X$ & $\begin{array}{c}\mathrm{HAR}-\mathrm{F}_{\mathrm{R}} \\
\left({ }^{*} \mathrm{BF}\right)\end{array}$ & SFXUNI & $\begin{array}{c}\mathrm{HAR}-\mathrm{F}_{\mathrm{L}} \\
\left({ }^{*} \mathrm{FB}\right)\end{array}$ & $\begin{array}{c}\mathrm{HAR} \mathrm{N}_{\mathrm{L}} \\
\left({ }^{*} \mathrm{NB}\right)\end{array}$ \\
\hline $\begin{array}{c}\text { a. }{ }^{*} \emptyset \mathrm{t}-\mathrm{B} \\
\text { øt-F}\end{array}$ & & $*\{-\mathrm{F}\}$ & $*(\varnothing \mathrm{B})$ & \\
\hline $\begin{array}{l}* \text { b. }{ }^{* \text { hat }-B} \\
\text { hat-F }\end{array}$ & $*(\mathrm{aF})$ & $*\{-\mathrm{F}\}$ & & \\
\hline
\end{tabular}

(9) below shows that ranking of phonological and morphological constraints we have used in the analysis so far. It can be seen that the morphological (uniformity) constraints are interleaved with, i.e. ordered in between the phonological harmony constraints which penalise various instances of disharmony. The highest ranking (morphological) constraint STEMUNI that occurs in (9) has been (and will be) left out from the tableaux for simplicity's sake. It is a uniformity constraint that penalises harmony alternations in roots. Its top ranking expresses the fact that Hungarian harmony is root controlled and that in present day Hungarian harmony does not apply to borrowed disharmonic roots or between the constituents of disharmonic compounds. ${ }^{29}$

(9) The ranking of phonological and morphological constraints

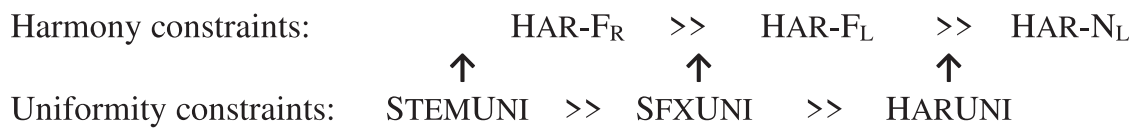

\subsection{Transparency and opacity}

We will now examine the transparent behaviour of neutral vowels (and the opaqueness of harmonic ones (see (1) above). In the analysis above we considered $\varepsilon$ a front harmonic vowel (F) because it does not occur (i) in antiharmonic stems (systematically) and (ii) in invariable suffixes. Here, because of its variable transparency/opacity in roots, we will have harmony constraints specific to $\varepsilon$ and it is not a member of the set $\mathrm{F}$ (or $\mathrm{N}$ ) either. In order to model transparency, we distinguish two versions of each harmony constraint, a local one and a non-local one (cf. Hayes \& Cziráky Londe 2006; Hayes et al. 2009). The former penalises strictly ${ }^{30}$ adjacent (strong or weak)

\footnotetext{
${ }^{29}$ Historically this was not always the case.

${ }^{30}$ Consonants are essentially invisible to vowel harmony in Hungarian, so strictly adjacent vowels are those that are not separated by other vowels (for a limited role consonants may play, see Hayes et al. (2009), Patay (2019), Patay et al. (2019).
} 
disharmony and the latter one penalises non-adjacent (strong or weak) disharmony. As the effect of the local version of a constraint is naturally stronger than that of the non-local version we assume that the rank of the local version is universally higher than the non-local version of the same constraint. $(10 \mathrm{i}, \mathrm{ii})$ is an analysis of the complete transparency of neutral vowels $\left(\mathbf{i}, \mathbf{i}, \mathbf{e}, \mathbf{e}^{31}\right.$ vs. the full opacity of harmonic ones $(F=\{\boldsymbol{\emptyset}, \boldsymbol{\emptyset}, \mathbf{y}, \mathbf{y :}\}, \mathrm{B}=\{\mathbf{u}, \mathbf{u}: \mathbf{o}, \mathbf{o}: \mathbf{a}, \mathbf{a}:\})$. (10i, ii) compare local and non-local strong disharmony $\left({ }^{*} \mathrm{FB},{ }^{*} \mathrm{BF},{ }^{*} \mathrm{~B}\right.$. . F, $\left.{ }^{*} \mathrm{~F} . \mathrm{B}\right)$ to weak disharmony $\left({ }^{*} \mathrm{NB}\right)$ between stem and target suffix (10i): $[\mathrm{BF}]$ and $[\mathrm{BN}]$ stems; (10ii): [FB] and [FN] stems). In (10i:b) the grammatical form Jofø:r-yyk 'chauffeur-1PL' wins although it has non-local strong disharmony (B...F). The competing candidate form * foførr-unk violates the constraint banning local strong disharmony, which shows that the local constraint must be ranked higher. In (10ii:a) the grammatical candidate papi:r-unk 'paper-1PL' has local weak disharmony while the competing ungrammatical one has non-local strong disharmony. This shows that $\mathrm{HAR}_{\mathrm{R}}-\mathrm{F}_{\mathrm{R}}-\mathrm{NonLOC}$ must be ranked higher than HAR- $\mathrm{N}_{\mathrm{L}}$-LOC, which results in the transparency of neutral vowels. When local and non-local harmony constraints applying to different sets of vowels of an inventory are ordered so that the non-local constraint dominates the local one, then the set of vowels the local constraint refers to are transparent. In (10ii:d) the grammatical form krø:zuf-unk 'extremely.rich.person-1PL' is selected because even though it has non-local strong disharmony (F...B), the competing ungrammatical candidate form *krø:zuf-ynk violates the higher ranking constraint banning local strong disharmony. In (10ii:c) it is the completely harmonic form kø:rif-ynk 'ash.tree-1PL' violating no constraint at all that is selected over the competing ungrammatical form *kørif-unk, which has non-local strong disharmony, violating $\mathrm{HAR}-\mathrm{F}_{\mathrm{L}}-\mathrm{NONLOC}$ (the form is also locally weakly disharmonic, violating HAR- $\mathrm{N}_{\mathrm{L}}$-LOC, redundantly).

(10i) Transparency of neutral vowels and opacity of front harmonic vowels

\begin{tabular}{|c|c|c|c|}
\hline$R O O T+1 P L$ & $\begin{array}{c}\text { HAR-F }_{L} \\
\text { LOC } \\
(* \mathbf{F B})\end{array}$ & $\begin{array}{c}\text { HAR-F }_{\mathrm{R}} \\
\text { NonLoC } \\
\left({ }^{*} \mathrm{~B} . . \mathrm{F}\right)\end{array}$ & $\begin{array}{c}{\text { HAR }-N_{L}} \\
\text { LoC } \\
(* N B)\end{array}$ \\
\hline $\begin{array}{l}\text { a. papi:r-unk } \\
\text { *papirr-ynk }\end{array}$ & & $*(\mathrm{a} \ldots \mathrm{y})$ & $*(\mathrm{iu})$ \\
\hline 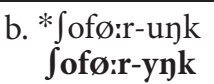 & $*(\varnothing \mathrm{u})$ & $*(\mathrm{o} . . . \mathrm{y})$ & \\
\hline
\end{tabular}

(10ii) Opacity of back vowels

\begin{tabular}{|c|c|c|c|}
\hline$R O O T+1 P L$ & $\begin{array}{c}\mathrm{HAR}_{\mathrm{A}} \mathrm{F}_{\mathrm{R}} \\
\text { LOC } \\
(* \mathrm{BF})\end{array}$ & $\begin{array}{c}\text { HAR-F }_{\mathrm{L}} \\
\text { NonLoc } \\
\left({ }^{*} \mathrm{~F} . . . \mathrm{B}\right)\end{array}$ & $\begin{array}{c}{\text { HAR }-N_{L}} \\
\text { LoC } \\
(* N B)\end{array}$ \\
\hline $\begin{array}{l}\text { c. *kø:rif-unk } \\
\text { kø:rif-ynk }\end{array}$ & & $*(\varnothing \ldots \mathrm{u})$ & $*(\mathrm{iu})$ \\
\hline 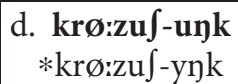 & *(uy) & $*(\varnothing \ldots \mathrm{u})$ & \\
\hline
\end{tabular}

\footnotetext{
${ }^{31}$ Here we abstract away from the lexical variation in transparency with [. . Be:] stems discussed in Section (2.1).
} 
In the analysis each harmony constraint has three parameters: (I) strong vs. weak disharmony involving phonetically front vowels is distinguished (HAR-F, HAR-N, respectively); (II) left vs. right orientation is distinguished depending on whether the disharmonic $\mathrm{B}$ vowel precedes $\mathrm{L}$ (eft) or follows R(ight) the phonetically front vowel; and (III) local vs. non-local disharmony is distinguished depending on whether the vowels in the disharmonic string are strictly adjacent (LOCAL) or separated by other vowels (NONLOCAL). The ordering of these constraints is summarised in the Hasse diagram in (11) below, where two views ((a) locality, (b) direction) of the same ranking are shown.

Hasse diagram of harmony constraint ranking

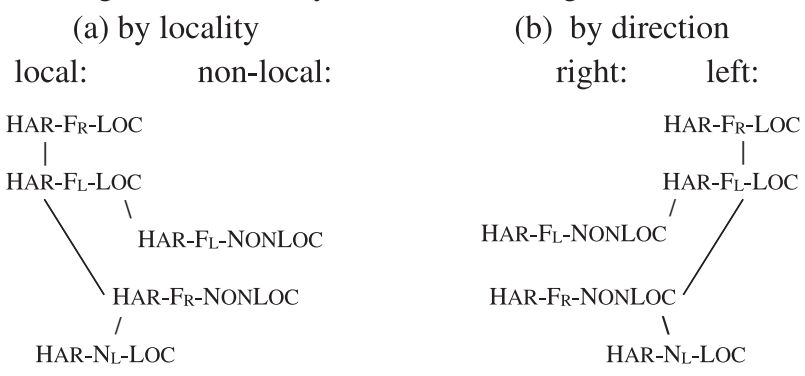

\subsection{Vacillation: the Count Effect and the Height Effect}

We can now turn to the analysis of vacillation, first the Count Effect. In order to model the Count Effect we have to distinguish versions of the non-local harmony constraints according to the distance between the vowels in strong disharmony measured in the number of intervening vowels. Specifically, we have to distinguish $\operatorname{HAR}-\mathrm{F}_{\mathrm{R}}(1)$ (when there is exactly one vowel between a back harmonic vowel and a following non-neutral front vowel $\left({ }^{*} \mathrm{BVF}\right)$ ) and HAR-FR $(\geq 2)$ (when there is more than one vowel between a back harmonic vowel and a following nonneutral front vowel $\left.\left({ }^{*} \mathrm{BVV}+\mathrm{F}\right)\right){ }^{32}$ Similarly, we distinguish versions of some harmony constraints penalising non-local weak disharmony: HAR- $\mathrm{N}_{\mathrm{L}}(1), \mathrm{HAR}_{\mathrm{L}} \mathrm{N}_{\mathrm{L}}(2), \mathrm{HAR}_{\mathrm{L}}(3)$ ( ${ }^{*} \mathrm{NVB}$, *NVVB, *NVVVB).

The candidates we are considering in (12i) all have more than one neutral vowel between a back harmonic vowel and the harmonically alternating suffix: (12i:abc) have two and (12i:d) have three. The constraints measure how far the (back) harmonic vowel is from the suffix vowel and not many neutral vowels separate them. It can be seen in (12i) that it does not matter whether the last (back) harmonic vowel of the stem is preceded by no vowel (12i:a), another back vowel (12i:b) or a neutral one (12i:c) and it also does not matter if there are two $(12 \mathrm{i}: \mathrm{abc})$ or three (12i:d) neutral vowels separating the back stem vowel from the suffix. The possible differences (the different ways they may violate the HAR- $\mathrm{N}_{\mathrm{L}}$ constraints) between these cases are all recessive because the selection of the candidates is determined by the higher-ranking constraints $\operatorname{HAR}-\mathrm{F}_{\mathrm{R}}(\geq 2)$ banning strong

\footnotetext{
${ }^{32}$ In this notation $(0)$ indicates that the constraint is a local one, e.g. HAR- $\mathrm{N}_{\mathrm{L}}(0)=$ HAR- $\mathrm{N}_{\mathrm{L}}-\mathrm{LOC}$.
} 
$\geq 2$ non-local disharmony between the back vowel(s) of the stem and the suffix vowel and HAR- $\mathrm{N}_{\mathrm{L}}(0)$ banning weak local disharmony between the last neutral vowel of the stem and the suffix vowel. These higher ranking constraints themselves are not ranked and under a partially ordered constraints interpretation (Kager 2000; Anttila 2007; Coetzee \& Pater 2011) in which such a "tie" means two total orders consistent with the partial ordering (one in which $\operatorname{HAR}-\mathrm{F}_{\mathrm{R}}(\geq 2)$ ranks higher than $\operatorname{HAR}-\mathrm{N}_{\mathrm{L}}(0)$ and one in which the order is the reverse) the result is the attested vacillation (one candidate is selected by one ordering and the other one be the other). ${ }^{33}$

Variable transparency (Count Effect: $[\ldots \mathrm{BNN}(\mathrm{N})]$ roots) ${ }^{34}$

\begin{tabular}{|c|c|c|c|c|c|}
\hline$R O O T+1 P L$ & $\begin{array}{c}{\text { HAR }-F_{R}} \\
\quad(\geq 2) \\
\text { * }^{\mathbf{B V V}^{+} \mathbf{F}}\end{array}$ & $\begin{array}{c}\text { HAR- } \mathrm{N}_{\mathrm{L}} \\
\quad(0) \\
* \mathrm{NB}\end{array}$ & $\begin{array}{c}\text { HAR- } \mathrm{N}_{\mathrm{L}} \\
\quad(1) \\
* \mathrm{NVB}\end{array}$ & $\begin{array}{c}\text { HAR- } \mathrm{N}_{\mathrm{L}} \\
\quad(2) \\
\text { *NVVB }\end{array}$ & $\begin{array}{c}\text { HAR-N }_{L} \\
(3) \\
\text { *NVVVB }\end{array}$ \\
\hline $\begin{array}{r}\text { a. aspirin-unk } \\
\text { aspirin-ynk }\end{array}$ & $*(\mathrm{a} \ldots \mathrm{y})$ & $*(\mathrm{iu})$ & $*(\mathrm{i} . . . \mathrm{u})$ & & \\
\hline $\begin{array}{l}\text { b. anali:zif-unk } \\
\text { anali:zif-ynk }\end{array}$ & $* *(\mathrm{a} \ldots \mathrm{y})$ & $*(\mathrm{iu})$ & $*(\mathrm{i} . . . \mathrm{u})$ & & \\
\hline 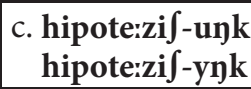 & $*(\mathrm{o} \ldots \mathrm{y})$ & $*(\mathrm{iu})$ & $*(\mathrm{i} \ldots \mathrm{u})$ & & $*(\mathrm{i} . . . \mathrm{u})$ \\
\hline $\begin{array}{l}\text { d. horribilif-unk } \\
\text { horribilif-ynk }\end{array}$ & $*(\mathrm{o} \ldots \mathrm{y})$ & $*(\mathrm{iu})$ & $*(\mathrm{i} \ldots \mathrm{u})$ & $*(\mathrm{i} \ldots \mathrm{u})$ & \\
\hline
\end{tabular}

Note that right-oriented constraints referring to $F$ (such as $\operatorname{HAR}_{\mathrm{R}}(\geq 2)$ in (12i)) and comparable constraints referring to $\mathrm{N}$ and $\varepsilon$ behave in the same way since these constraints always apply between the stem and the suffix and F, $\varepsilon$ and $\mathrm{N}$ vowels behave in the same way in suffixes (except for the single case of invariant $\mathrm{N}$ suffixes, which do not alternate because of a dominant uniformity constraint SFXUNI, cf. (8ii)).

(12ii) presents an analysis of the Height Effect, specifically the intermediate status of $\varepsilon$ between fully harmonic and fully neutral vowels in stems (rather than suffixes) which manifests itself in vacillation after $[\ldots \mathrm{B} \varepsilon]$ stems. The candidates in (12ii) are all $[\ldots \mathrm{B} \varepsilon]$ stems, the difference between them is in the vowel preceding the last back vowel of the stem. We can see that it makes no difference whether the last (back) harmonic vowel of the stem is preceded by no vowel (12ii:a), another back vowel (12ii:b), $\boldsymbol{\varepsilon}$ (12ii:c) or a neutral one (12ii:d): vacillation occurs in all these cases. ${ }^{35}$ In order to model variable transparency of $\varepsilon[\ldots B \varepsilon]$ roots, we need harmony constraints specific to $\varepsilon$, which can be ordered independently of (relative to) harmony

\footnotetext{
${ }^{33}$ The analysis in this paper says nothing about the relative frequency of candidates in vacillation, we only distinguish variation from the lack of variation (compare other analyses that aim to model the probabilities/frequencies, too: Hayes \& Cziráky Londe 2006; Hayes et al. 2009).

${ }^{34}$ Glosses: aspirin 'aspirin', anali:zis 'analysis', hipote:zi؟ 'hypothesis', horribilif 'horrible'.

${ }^{35}$ Here we abstract away from the lexical variation in transparency with [...Be] stems discussed in Section (2.1).
} 
constraints referring to harmonic vowels $(\mathrm{F})$ and neutral vowels $(\mathrm{N})$ : the local constraint HAR$\varepsilon_{\mathrm{L}}(0)$ and the non-local one HAR- $\varepsilon_{\mathrm{L}}(2)$. For $[\ldots \mathrm{B} \varepsilon]$ roots the relevant one is $\operatorname{HAR}-\varepsilon_{\mathrm{L}}(0)$, which penalises the back harmonic one of the competing candidate forms. If this constraint ranks high and is unordered with respect to the constraint that penalises the other (front harmonic) candidate, then the attested vacillation results (e.g. fotcl-unk/fotel-ynk) under the partial ordering approach to variation. Since these constraints uniquely determine the selection of candidates, the lower ranking (non-local) constraints have no effect (here). ${ }^{36}$

Variable transparency of $\varepsilon$ (Height Effect: [ . .B $\varepsilon]$ roots) ${ }^{37}$

\begin{tabular}{|c|c|c|c|c|c|}
\hline$R O O T+1 P L$ & $\begin{array}{c}\text { HAR- } F_{\mathrm{R}} \\
(1) \\
*_{\mathrm{BVF}}\end{array}$ & $\begin{array}{c}\text { HAR }-\varepsilon_{\mathrm{L}} \\
(0) \\
* \boldsymbol{\varepsilon} \mathbf{B}\end{array}$ & $\begin{array}{c}\text { HAR-F } F_{R} \\
\quad(\geq 2) \\
\text { * } \mathbf{B V V}^{+} \mathbf{F}\end{array}$ & $\begin{array}{c}\text { HAR- } \varepsilon_{L} \\
(2) \\
* \boldsymbol{\varepsilon} \mathbf{V V B}\end{array}$ & $\begin{array}{c}\text { HAR-N }_{L} \\
(2) \\
\text { *NVVB }\end{array}$ \\
\hline $\begin{array}{l}\text { a. fotel-unk } \\
\text { fotel-ynk }\end{array}$ & $*(0 . . y)$ & $*(\varepsilon \mathrm{u})$ & & & \\
\hline 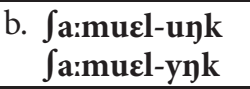 & $*(\mathrm{o} \ldots \mathrm{y})$ & $*(\varepsilon \mathrm{u})$ & $*(\mathrm{a} . . . \mathrm{y})$ & & \\
\hline $\begin{array}{l}\text { c. leander-unk } \\
\text { leander-ynk }\end{array}$ & $*(\mathrm{o} \ldots \mathrm{y})$ & i $\quad *(\varepsilon \mathrm{u})$ & & $*(\varepsilon \ldots \mathrm{u})$ & \\
\hline $\begin{array}{l}\text { d. tsino:ber-unk } \\
\text { tsino:ber-ynk }\end{array}$ & $*(\mathrm{o} \ldots \mathrm{y})$ & $*(\varepsilon \mathrm{u})$ & & & $*(\mathrm{i} . . . \mathrm{u})$ \\
\hline
\end{tabular}

(12iii) is an analysis of the interaction between the Height Effect and the Count Effect. Accordingly, it combines the constraints (with their ranking) in (12i) and (12ii). The candidates considered are forms where the last back vowel of the root is separated form the suffix vowel by two or more phonetically front vowels one or more of which is $\varepsilon$ while the others (if there are others in addition to $\varepsilon$ ) are neutral i, i:, e:. As we have seen in Section 2.2. the position of $\varepsilon$ is crucial in these forms: there is vacillation if the last phonetically front vowel of the root is not $\varepsilon$ (12iii:abc) but only the form with the front alternant of the suffix is grammatical if it is $\varepsilon$ (12iii:def). Note that in (12iii) the non-local constraints penalising disharmony with $\varepsilon$ or a neutral vowel are recessive and do not play a part in the selection of the grammatical candidate(s), i.e. as long as the last vowel of the root is a neutral vowel or $\varepsilon$ it does not matter if a preceding phonetically front vowel is a neutral vowel or $\varepsilon$ (we find vacillation or no vacillation irrespectively). ${ }^{38}$ It is the constraints we found active in (12i) and (12ii) combined that select the grammatical candidates here. The members of the pairs of constraints, non-local HAR- $F_{R}(1)$, local $\operatorname{HAR}-\varepsilon_{L}(0)$ (cf. (12ii)) and non-local HAR-F $F_{R}(\geq 2)$,

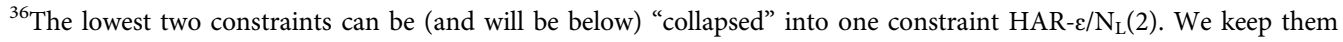
apart in (12ii) to show their violations separately for expository purposes.

${ }^{37}$ Glosses: fotel 'armchair', Ja:muعl 'Samuel', leander 'oleander', tsino:ber 'vermillion'.

${ }^{38}$ These constraints (the lowest three) can be (and will be below) "collapsed" into one constraint $H A R-\varepsilon / N_{L}(\geq 1)$. We keep them apart in (12iii) to show their violations separately for expository purposes.
} 
HAR- $\mathrm{N}_{\mathrm{L}}(0)$ (cf. (12i)) are not ordered themselves but the two pairs are: the first pair ranks above the second one. This is crucial because the candidates whose last root vowel is not $\varepsilon$ (12iii:abc) do not violate either member of the pair of constraints $\operatorname{HAR}-\mathrm{F}_{\mathrm{R}}(1)$, local HAR$\varepsilon_{L}(0)$ and therefore the lower ranking pair of constraints $\operatorname{HAR}-\mathrm{F}_{\mathrm{R}}(\geq 2), \operatorname{HAR}-\mathrm{N}_{\mathrm{L}}(0)$ determine the selection of forms. Since these are not ordered, vacillation results in the same way as in the tableaux above.

There is no vacillation (only the candidate forms with a front suffix alternant are selected), however, if the last root vowel is $\boldsymbol{\varepsilon}$ (12iii:def) because in this case $\operatorname{HAR}-\varepsilon_{\mathrm{L}}(0)$ of the higher ranking pair is violated by the candidate forms with a back suffix alternant $\left({ }^{*} \varepsilon B\right)$ and therefore it does not matter how the candidates fare on the lower ranking pair of constraints (which favour the candidates with a back suffix alternant).

(12iii) Variable and blocked transparency of $\varepsilon$ (Height Effect \& Count Effect: $\left[\ldots \mathrm{B}^{+} \mathrm{N}^{+}\right]$, $\left[\ldots \mathrm{BN}^{+} \varepsilon^{+}\right]$and $\left[\mathrm{Br \varepsilon}^{+}\right]$roots $)^{39}$

\begin{tabular}{|c|c|c|c|c|c|c|c|}
\hline$R O O T+1 P L$ & $\begin{array}{c}\text { HAR-F }_{\mathrm{R}} \\
(1) \\
\text { * }^{\text {BVF }}\end{array}$ & $\begin{array}{c}(0) \\
*_{\varepsilon B} B\end{array}$ & $\begin{array}{c}{\text { HAR }-F_{\mathrm{R}}}^{(\geq 2)} \\
{ }^{*} \mathbf{B V V}^{+} \mathbf{F}\end{array}$ & $\begin{array}{c}\mathrm{N}_{\mathrm{L}} \\
(0) \\
* \mathrm{NB}\end{array}$ & $\begin{array}{c}\text { HAR- } \\
\varepsilon / \mathrm{N}_{\mathrm{L}} \\
(1) \\
* \boldsymbol{\varepsilon} / \mathbf{N V B}\end{array}$ & $\begin{array}{c}\mathrm{HAR}-\boldsymbol{\varepsilon} / \mathrm{N}_{\mathrm{L}} \\
(2) \\
* \boldsymbol{\varepsilon} / \mathbf{N V V B}\end{array}$ & $\begin{array}{c}\mathrm{HAR}-\boldsymbol{\varepsilon} / \mathrm{N}_{\mathrm{L}} \\
(3) \\
*_{\boldsymbol{\varepsilon}} / \mathbf{N V V V B}\end{array}$ \\
\hline $\begin{array}{l}\text { a. sutcre:n-unk } \\
\text { sutcre:n-ynk }\end{array}$ & & $\begin{array}{l}1 \\
1\end{array}$ & $*(\mathrm{u} . . . \mathrm{y})$ & $*(\mathrm{eu})$ & 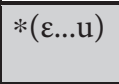 & & \\
\hline $\begin{array}{r}\text { b. kompetiti:v-unk } \\
\text { kompetiti:v-ynk }\end{array}$ & & $\begin{array}{l}1 \\
1\end{array}$ & $*(\mathrm{o} \ldots \mathrm{y})$ & $*(\mathrm{iu})$ & $*(\mathrm{i} \ldots \mathrm{u})$ & $*(\varepsilon \ldots u)$ & \\
\hline $\begin{array}{l}\text { c. \%kolesterin-unk } \\
\text { kolesterin-ynk }\end{array}$ & & & $*(\mathrm{o} \ldots \mathrm{y})$ & $*(\mathrm{iu})$ & *(ع...u $)$ & $*(\varepsilon \ldots u)$ & \\
\hline $\begin{array}{l}\text { d. *konte:ner-unk } \\
\text { konte:ner-ynk }\end{array}$ & & $*(\varepsilon \mathrm{u})$ & $*(\mathrm{o} \ldots \mathrm{y})$ & i & $*(\mathrm{e} \ldots \mathrm{u})$ & & \\
\hline $\begin{array}{l}\text { e. *dijabe:tes-unk } \\
\text { dijabe:tes-ynk }\end{array}$ & & $*(\varepsilon \mathrm{u})$ & $*(\mathrm{a} \ldots \mathrm{y})$ & 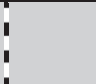 & $*(\mathrm{e} \ldots \mathrm{u})$ & & $*(\mathrm{i} . . . \mathrm{u})$ \\
\hline $\begin{array}{l}\text { f. *propel:er-unk } \\
\text { propel:er-ynk }\end{array}$ & & $*(\varepsilon u)$ & *(o...y) & I & *(ع...u $)$ & & \\
\hline
\end{tabular}

The examples we examine in (13i) and (13ii) are all disharmonic roots in the sense that they contain front harmonic (F) vowels and also back harmonic vowels (B) in some of their syllables. (13i:abc) show that it is the last harmonic vowel (in this case a back vowel) that determines the harmonic behaviour of the root, i.e how it fares on the highest harmony constraint, local HAR- $\mathrm{F}_{\mathrm{R}}(0)$. It does not matter what kinds of vowels (e.g. a front harmonic vowel) precede the last back vowel, i.e. the non-local harmony constraints that refer to these vowels are recessive and have no part in the selection of the grammatical candidates. (13i:de) are examples where the last back harmonic vowel (preceded by a front harmonic one) is followed by a neutral vowel (13i:d) or $\varepsilon$ and a neutral vowel (13i:e). We expect full

${ }^{39}$ Glosses: sutere:n 'basement', kompetiti:v 'competitive', kolesterin 'cholesterin', dijabe:tes 'diabetes', propel:er 'propeller'. 
transparency in the former case (see Section 2.1) and vacillation due to the Count Effect in the latter (see Section 2.2). This is achieved by ordering the left-oriented local and non-local constraints, specifically HAR- $\mathrm{F}_{\mathrm{L}}(2)$ and $\mathrm{HAR}-\mathrm{N}_{\mathrm{L}}(0)$ below $\mathrm{HAR}-\mathrm{F}_{\mathrm{R}}(1)$. (13i:e) shows that leftoriented non-local HAR- $\mathrm{F}_{\mathrm{L}}(\geq 3)$ and HAR-N/ $\varepsilon_{\mathrm{L}}(\geq 1)$ must be ordered below the unordered non-local HAR- $\mathrm{F}_{\mathrm{R}}(\geq 2)$, local $\mathrm{HAR}-\mathrm{N}_{\mathrm{L}}(0)$ for vacillation to occur. Again, full transparency (13i:d) and vacillation due to the Count Effect (13i:e) occur irrespective of what kind of vowel precedes the last full vowel.

Harmonic back suffixation of disharmonic roots ${ }^{40}$

\begin{tabular}{|c|c|c|c|c|c|c|c|c|}
\hline$S T E M+A B L$ & $\begin{array}{c}\text { HAR-F } \\
(0) \\
\left({ }^{*} \mathbf{B F}\right)\end{array}$ & $\begin{array}{c}\text { HAR-F } \\
\text { (1) } \\
\text { * FVB }\end{array}$ & $\begin{array}{c}\mathrm{HAR}-\mathrm{F}_{\mathrm{R}} \\
(1) \\
\left({ }^{*} \mathrm{BVF}\right)\end{array}$ & $\begin{array}{c}\text { HAR-F } \\
\text { (2) } \\
\text { *FVVB }\end{array}$ & $\begin{array}{c}\text { HAR-F } \\
(\geq 2) \\
* \mathbf{B V F}^{+} \mathbf{F}\end{array}$ & $\begin{array}{c}\text { HAR- } \mathrm{N}_{\mathrm{L}} \\
(0) \\
\left({ }^{*} \mathrm{NB}\right)\end{array}$ & $\begin{array}{c}\mathrm{HAR}-\mathrm{F}_{\mathrm{L}} \\
(\geq 3) \\
* \mathbf{F V} \geq 3 \mathbf{B}\end{array}$ & $\begin{array}{c}\text { HAR- } \\
\mathrm{N} / \varepsilon_{\mathrm{L}} \\
(\geq 1) \\
* \mathrm{NV}^{+} \mathbf{B}\end{array}$ \\
\hline $\begin{array}{l}\text { a. krø:zus-to:l } \\
\text { *krø:zus-tø:l }\end{array}$ & $*(\mathrm{u} \emptyset)$ & *(Ø...o) & & & & & & \\
\hline $\begin{array}{l}\text { b. amø:ba:-to:l } \\
\text { *amø:ba:-tø:l }\end{array}$ & $*(\mathrm{a} \varnothing)$ & $*(\varnothing \ldots)$. & $*(\mathrm{a} \ldots \varnothing)$ & & & & & \\
\hline $\begin{array}{l}\text { c. ødipus-to:l } \\
{ }^{*} \text { ødipus-tø:l }\end{array}$ & $*(\mathrm{u} \emptyset)$ & & & $*(\varnothing \ldots)$. & & & & $*(\mathrm{i} \ldots \mathrm{o})$ \\
\hline $\begin{array}{r}\text { d. tsøno:zis-to:l } \\
\text { *tsøno:zis-tø:l } \\
\end{array}$ & & & $*(0 \ldots \varnothing)$ & $*(\varnothing \ldots o)$ & & $*$ (io) & & \\
\hline $\begin{array}{l}\text { e. } ø \text { kumene:-to:l } \\
\text { økumene:-tø:l }\end{array}$ & & & & & $*(\mathrm{u} \ldots \varnothing)$ & $*(\mathrm{eo})$ & $*(\varnothing \ldots 0)$ & $*(\varepsilon \ldots o)$ \\
\hline
\end{tabular}

(13ii) makes a similar point about disharmonic roots, but this time the last harmonic vowel is front (which is preceded by back harmonic or neutral vowels or both). In the candidate forms in (13ii:abc) this front harmonic vowel immediately precedes the harmonically alternating suffix (they differ in the vowels that precede the last harmonic vowel). Accordingly, the grammatical forms are selected by the highest ranking local constraint penalising strong disharmony with the back alternant of a suffix $\mathrm{HAR}_{\mathrm{L}}(0)$. It does not matter what kinds of vowels (e.g. a back harmonic vowel) precede the last front vowel, i.e. the non-local harmony constraints that refer to these vowels are recessive and have no part in the selection of the grammatical candidates. (13ii:de) are examples where the last front harmonic vowel (preceded by a back harmonic one) is followed by a neutral vowel (13ii:d) or more than one neutral vowel (13ii:e). Here we expect no vacillation in either case since the root-final neutral vowels are immediately preceded by a front harmonic vowel. This is implemented by ranking the unordered pair of constraints that can drive vacillation in other cases $\left(H A R-F_{R}(\geq 2)\right.$, HAR$\mathrm{N}_{\mathrm{L}}(0)$ below the constraints penalising "more local" left-oriented strong disharmony (HAR$\mathrm{F}_{\mathrm{L}}(1)$ and $\mathrm{HAR}-\mathrm{F}_{\mathrm{L}}(2)$, which select the grammatical candidate forms with front suffix alternants.

\footnotetext{
${ }^{40}$ Glosses: amø:ba 'amoeba', ødipus ‘Oedipus', økumøne: 'Christians' pursuit of unity', tsøno:zis 'cenosis'.
} 
Harmonic front suffixation of disharmonic roots ${ }^{41}$

\begin{tabular}{|c|c|c|c|c|c|c|c|}
\hline$S T E M+A B L$ & $\begin{array}{c}{\text { HAR }-\mathrm{F}_{\mathrm{L}}} \\
(0) \\
{ }^{*} \mathbf{F B} \\
\end{array}$ & $\begin{array}{c}\text { HAR-F } \\
(1) \\
\left({ }^{*} \mathbf{B V F}\right)\end{array}$ & $\begin{array}{c}\text { HAR-F }_{L} \\
(1) \\
\text { * FVB } \\
\end{array}$ & $\begin{array}{c}\text { HAR-F }_{L} \\
(2) \\
\text { * FVVB } \\
\end{array}$ & $\begin{array}{c}\mathrm{HAR}^{\mathrm{HAR}}-\mathrm{F}_{\mathrm{R}} \\
(\geq 2) \\
* \mathbf{B V V}+\mathbf{F}\end{array}$ & $\begin{array}{c}\text { HAR-N } \\
(0) \\
\left({ }^{*} \mathbf{N B}\right) \\
\end{array}$ & $\begin{array}{c}\mathrm{HAR}-\mathrm{N} / \varepsilon_{\mathrm{L}} \\
(\geq 1) \\
* \mathrm{NV}^{+} \mathbf{B}\end{array}$ \\
\hline 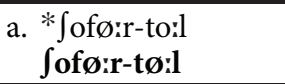 & $*(\varnothing о)$ & $*(\mathrm{o} \ldots \varnothing)$ & & & & & \\
\hline $\begin{array}{l}\text { b. *amatø:r-to:l } \\
\text { amatø:r-tø:l }\end{array}$ & $*(\varnothing 0)$ & $*(\mathrm{a} \ldots \varnothing)$ & & & $*(\mathrm{a} \ldots \varnothing)$ & & \\
\hline $\begin{array}{l}\text { c. *attity:d-to:l } \\
\text { attity:d-tø:l }\end{array}$ & $*(\mathrm{yo})$ & & & & $*(\mathrm{a} \ldots \varnothing)$ & & $*(\mathrm{i} . . . \mathrm{o})$ \\
\hline $\begin{array}{l}\text { d. *karybdis-to:l } \\
\text { karybdis-tø:l }\end{array}$ & & & $*(\mathrm{y} \ldots \mathrm{o})$ & & $*(\mathrm{a} \ldots \varnothing)$ & $*$ (io) & \\
\hline $\begin{array}{l}\text { e. *kommynike:-to:l } \\
\text { kommynike:-tø:l }\end{array}$ & & & & $*(\mathrm{y} \ldots \mathrm{o})$ & $*(\mathrm{a} \ldots \varnothing)$ & $*(\mathrm{eo})$ & $*(\mathrm{i} \ldots \mathrm{o})$ \\
\hline
\end{tabular}

(14) below summarises the ranking of the harmony constraints we have discussed. We use separate lines for the right-oriented (first line) and the left oriented (second line) constraints to make (14) easier to read. A constraint to the left of another is ranked higher $(>>)$ and a pair of constraints are unranked if they do not appear to the left/right of one another. ${ }^{42}$

$$
\begin{aligned}
& \text { Ranking of harmony constraints }
\end{aligned}
$$

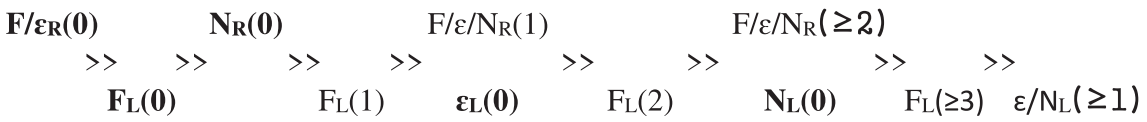

\subsection{Harmonic Uniformity}

We can now analyse the role of Harmonic Uniformity in transparency, which we discussed in Section 3.1. (15i), where the candidate forms have one or more invariant $\mathrm{N}$ suffixes preceding the final, harmonically alternating suffix, shows Harmonic Uniformity overriding the Count Effect. This manifests itself in blocking vacillation (which otherwise would result from the Count Effect) when the root itself does not induce vacillation (15i:bc). This is achieved by ranking Harmonic Uniformity above HAR- $\mathrm{F}_{\mathrm{R}}(\geq 2)$, HAR- $\mathrm{N}_{\mathrm{L}}(0)$ (the two active constraints in (12i), which are not

\footnotetext{
${ }^{41}$ Glosses: amatø:r 'amateur', karybdis 'Charybdis', kommynike: 'communiqué'.

${ }^{42}$ The orientation of harmony constraints, i.e. the ordering of left and right-oriented constraints (e.g. HAR- $F_{R}(0)>>$ HAR- $F_{L}$ ) is not really detectable within the root, because the number of disharmonic [FB] and [BF] roots is extremely low. The only root-internal phenomenon that makes this distinction is when it is $\varepsilon$ and not the F vowels that are in disharmony $([\varepsilon B]$ vs. $[\mathrm{B \varepsilon}]$ roots). The ordering of constraints applicable to these is $\mathrm{HAR}-\varepsilon_{\mathrm{R}}(0)>>\mathrm{HAR}-\varepsilon_{\mathrm{L}}(0)$. This manifests itself in the lexical status of $[\varepsilon B]$ and $[\mathrm{B} \varepsilon]$ roots. Roots in the latter group are all recent loans while those in the former group include older roots and placenames too (cf. e.g. Rebrus et al. 2020). This distribution is due to the fact that up to a period in Old Hungarian $B \varepsilon$ sequences were disallowed within the root while $\varepsilon B$ sequences were permitted (cf. Fejes \& Rebrus 2017). The ranking of the constraints $\mathrm{HAR}-\varepsilon_{\mathrm{R}}(0)>\mathrm{HAR}-\varepsilon_{\mathrm{L}}(0)$ is probably a reflection of this old distribution. While there are polymorphemic $\varepsilon B$ sequences (e.g. fotel-to:l), polymorphemic $B \varepsilon$ sequences are missing since there are no harmonically invariant suffixes with $\varepsilon$ (with the exception of some diminutives, cf. Rebrus \& Szigetvári (2016; 2021)).
} 
ranked with respect to one another). The higher ranking HARUNI filters out the candidate forms with a front harmonic suffix alternant ( ${ }^{*}$ madrid-i-tø:l, *ha:z-e:-i-tø:l) because the paradigms of the roots madrid and ha:z only have listed forms with back harmonic suffix alternants (see (5)). HARUNI does not have this effect when the paradigm of the root contains listed forms with back harmonic and front harmonic suffix alternants, too (15i:d). In this case neither candidate form (martinik-i-to:l, martinik-i-tø:l) violates HARUNI and selection is determined by the lower ranking constraints HAR- $F_{R}(\geq 2), H A R-N_{L}(0)$ (in the same way as in (12i)) and thus vacillation prevails. The candidate forms in (15i:a) are included for comparison. In this case the Count Effect does not apply (there is only one neutral vowel between the last back vowel of the root and the alternating suffix (i.e. HAR- $\mathrm{F}_{\mathrm{R}}(\geq 2)$ is inactive). The candidate form with a front suffix alternant (*ha:z-e:-tø:l) is excluded by the highest ranking constraint $\operatorname{HAR}_{\mathrm{R}} \mathrm{F}_{\mathrm{R}}(1)$ (e: is transparent) and also redundantly by HARUNI (the root ha:z only has forms with back suffix alternants in its paradigm), therefore ha:z-e:-to:l is selected - it makes no difference that the lower ranking relevant constraints (specifically HAR- $\mathrm{N}_{\mathrm{L}}(0)$ favour the front harmonic candidate form.

(Non-)blocking of variable transparency (HARUNI >> Count Effect)

\begin{tabular}{|c|c|c|c|c|c|}
\hline$S T E M+A B L$ & $\begin{array}{c}\text { HAR-F } \\
(1) \\
\left({ }^{*} \mathbf{B V F}\right)\end{array}$ & HARUNI & $\begin{array}{c}\text { HAR-F }_{\mathrm{R}} \\
(\geq 2) \\
\left({ }^{*} \mathbf{B} \mathbf{V} \mathbf{V}^{+} \mathbf{F}\right)\end{array}$ & $\begin{array}{c}\text { HAR-N }_{\mathrm{L}} \\
(0) \\
(* \mathbf{N B})\end{array}$ & $\begin{array}{c}\mathrm{HAR}-\mathrm{N}_{\mathrm{L}} \\
(\geq 1) \\
\left(* \mathbf{N V}^{+} \mathbf{B}\right)\end{array}$ \\
\hline $\begin{array}{l}\text { a. ha:z-e:-to:l } \\
\text { *ha:z-e:-tø:l }\end{array}$ & $*(\mathrm{a} \ldots \varnothing)$ & $*\{$ ha:z+B $\}$ & & $*(\mathrm{eo})$ & \\
\hline $\begin{array}{l}\text { b. madrid-i-to:l } \\
*_{\text {madrid-i-tø:l }}\end{array}$ & & $*\{\mathrm{~m} .+\mathbf{B}\}$ & $*(\mathrm{a} \ldots \varnothing)$ & $*($ io $)$ & $*(\mathrm{i} . . . \mathrm{o})$ \\
\hline $\begin{array}{l}\text { c. ha:z-e:-i-to:l } \\
\text { *ha:z-e:-i-tø:l }\end{array}$ & & $*\{$ ha:z $+\mathbf{B}\}$ & $*(\mathrm{a} \ldots \varnothing)$ & $*$ (io) & $*(\mathrm{e} \ldots \mathrm{o})$ \\
\hline $\begin{array}{l}\text { d. martinik-i-to:l } \\
\text { martinik-i-tø:l }\end{array}$ & & $\begin{array}{l}\{\mathrm{m} .+\mathbf{B}\} \\
\{\mathrm{m} .+\mathbf{F}\}\end{array}$ & $*(\mathrm{a} \ldots \varnothing)$ & (io) & $* *(\mathrm{i} . . . \mathrm{o})$ \\
\hline
\end{tabular}

(15ii) shows the behaviour of $[\mathrm{BN} / \varepsilon]$ roots. Similarly to (15i) the candidate forms have one or more invariant $\mathrm{N}$ suffixes preceding the final, harmonically alternating suffix. We can observe the same contrast between cases where HARUNI is active (because only one of the suffix alternants is found in the listed forms in the paradigm of the stem, (15ii:cd) vs. cases when it is inactive (because both of the suffix alternants are attested in the listed forms in the paradigm of the stem (15ii:abe) - only this time variation or the lack of variation is due to the Height Effect. In the former case it is either the back candidate form that violates HARUNI (15ii:c) or the front one (15ii:d) and therefore the lower ranking constraints play no part in the selection of the grammatical forms. In the latter case (15ii:abe) it is the highest ranking HARUNI which is not involved in the selection since both candidate forms satisfy it and thus the lower ranking constraints, crucially the unordered $\operatorname{HAR}-\mathrm{F}_{\mathrm{R}}(\geq 2)$ and $\mathrm{HAR}-\mathrm{N}_{\mathrm{L}}(0)$, determine the winner and therefore vacillation results. (The lowest ranking non-local constraints are not active in the selection in any of these cases). Note that the highest-ranking HARUNI constraint makes it possible to account for the lexical variation (see Section 2.1) in the behaviour of $[\mathrm{B \varepsilon}]$ and $[\mathrm{Be}$ : roots: it can distinguish those that induce vacillation (hotel, norve:g) from those that take front only (kontsert) or back only (kafte:j) suffix alternants. 
((Non-)blocking of variable transparency (HARUNI >> Height Effect) ${ }^{43}$

\begin{tabular}{|c|c|c|c|c|c|}
\hline$S T E M+A B L$ & HARUNI & $\begin{array}{c}\text { HAR-F }_{\mathrm{R}} \\
(\geq 2) \\
\left({ }^{*} \mathbf{B V V} \mathbf{V}^{+} \mathbf{F}\right)\end{array}$ & $\begin{array}{c}\text { HAR-N }_{\mathrm{L}} \\
(0) \\
(* \mathrm{NB})\end{array}$ & $\begin{array}{c}\text { HAR- } \varepsilon_{\mathrm{L}} \\
(\geq 1) \\
\left(* \varepsilon \mathrm{V}^{+} \mathbf{B}\right)\end{array}$ & $\begin{array}{c}\mathrm{HAR}-\mathrm{N}_{\mathrm{L}} \\
(\geq 1) \\
\left(* \mathbf{N V}^{+} \mathbf{B}\right)\end{array}$ \\
\hline $\begin{array}{l}\text { a. hotel-e: -to:l } \\
\text { hotel-e: -tø:l }\end{array}$ & $\begin{array}{l}\{\text { hotel+B }\} \\
\{\text { hot } 1+\mathbf{F}\}\end{array}$ & $*(\mathrm{o} \ldots \varnothing)$ & $*(\mathrm{eo})$ & $*(\varepsilon \ldots o)$ & \\
\hline $\begin{array}{l}\text { b. hotel-e: -i -to:l } \\
\text { hotel-e: -i -tø:l }\end{array}$ & $\begin{array}{l}\{\text { hot } \varepsilon l+\mathbf{B}\} \\
\{\text { hot } \varepsilon \text { l+F }\}\end{array}$ & $*(\mathrm{o} \ldots \varnothing)$ & $*$ (io) & $*(\varepsilon \ldots o)$ & $*(\mathrm{e} \ldots \mathrm{o})$ \\
\hline $\begin{array}{l}\text { c. *kontsert-e: -to:l } \\
\text { kontsert-e: -tø:l }\end{array}$ & $*\{$ kontsert $+\mathbf{F}\}$ & $*(\mathrm{O} \ldots \varnothing)$ & $*(\mathrm{eo})$ & $*(\varepsilon \ldots o)$ & \\
\hline 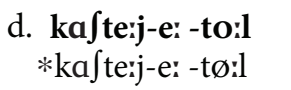 & $*\left\{\right.$ ka $\int$ te:j $\left.+\mathbf{B}\right\}$ & $*(\mathrm{a} \ldots \varnothing)$ & $*(\mathrm{eo})$ & & $*(\mathrm{e} \ldots \mathrm{o})$ \\
\hline $\begin{array}{l}\text { e. norve:g-e: -to:l } \\
\text { norve:g-e: -tø:l }\end{array}$ & $\begin{array}{l}\{\text { norve:g+B }\} \\
\{\text { norve:g+F }\}\end{array}$ & $*($ o...Ø) & *(io) & & $*(\mathrm{e} \ldots \mathrm{o})$ \\
\hline
\end{tabular}

(15iii) shows the analysis of "harmonic stability" effect ${ }^{44}$ we discussed in Section 3.1., when forms that contain a root alternant lacking the vowel that unambiguously determines harmony "inherit" the harmonic behaviour of the forms in their paradigm that have a root alternant in which the vowel is present. The forms in (15iii:bc) contain the "shortened" root allomorphs of a truncating stem be:n- and an epenthetic stem pisk- (the "full" allomorphs are be:na and pisok). It can be seen in (15iii) that HARUNI (which dominates the harmony constraints) selects the grammatical candidate forms independently of how the candidates fare on the harmony constraints. (15iii:a) is included to show that HARUNI is crucial because forms based on stems whose vocalic makeup is identical (be:k-i:t, be:n-itt) can be evaluated differently by HARUNI because the listed forms in their paradigms are harmonically different and this determines that the winner is the front harmonic form in (15iii:a) and the back harmonic one in (15iiib).

(15iii) Stems containing harmonic and anti-harmonic "shortened" bound roots

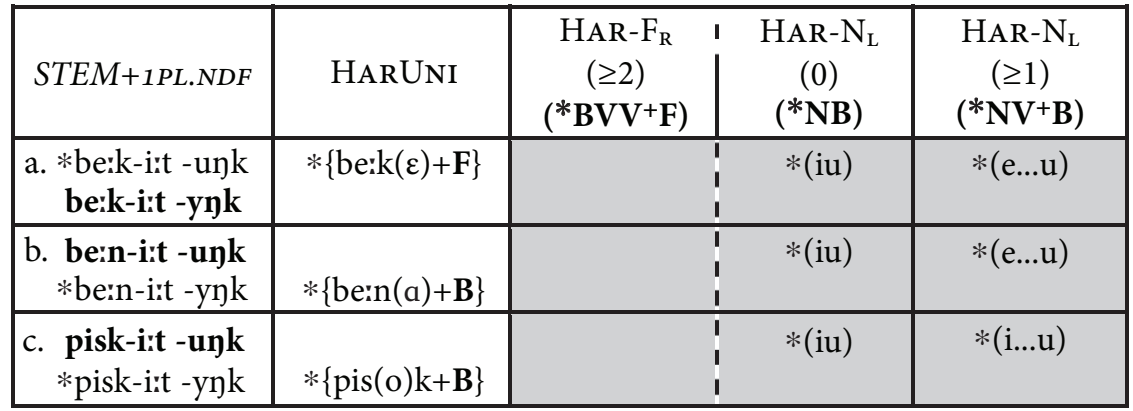

\footnotetext{
${ }^{43}$ Glosses: kafte:j 'castle', norve:g 'Norwegian'.

${ }^{44}$ This effect is not unlike tonal stability, cf. Goldsmith (1990).
} 
(15iv) is an analysis of harmonic and antiharmonic free roots that we have already analysed in (7ii), where we saw that the difference between the harmonic and antiharmonic behaviour of these roots is attributable to the high ranking HARUNI constraint. The only difference here is that in (7ii) we were examining forms of harmonic and antiharmonic $\mathrm{N}$ roots with a single harmonically alternating suffix and in (15iv) we are comparing these forms ((15iva), (15ivd)) to multiply suffixed forms based on the same roots where the harmonically alternating suffix is preceded by one or more invariant $\mathrm{N}$ suffix ((15ivbc), (15ivef)). We can see that the analysis works in the same way: the highest ranking HARUNI determines the selection of the winning candidate form based on the listed forms of the paradigms if the individual roots (the paradigm of harmonic hi:m only contains listed forms with front allomorphs of harmonic suffixes and the paradigm of antiharmonic hi:d only contains listed forms with back allomorphs of harmonic suffixes). The effect of the lower ranking harmony constraints is overridden by HARUNI whenever they are in conflict.

(15iv) Harmonic and anti-harmonic free roots

\begin{tabular}{|c|c|c|c|c|}
\hline$S T E M+D E L$ & HARUNI & $\begin{array}{c}\text { HAR-F } \\
(\geq 2) \\
\left(* \mathbf{B V V}^{+} \mathbf{F}\right) \\
\end{array}$ & $\begin{array}{c}\text { HAR-N } \mathrm{N}_{\mathrm{L}} \\
(0) \\
(* \mathbf{N B})\end{array}$ & $\begin{array}{c}\text { HAR-N } \\
(\geq 1) \\
\left(* N_{L}+\mathbf{B}\right)\end{array}$ \\
\hline $\begin{array}{r}\text { a. *hi:m -ro:l } \\
\text { hi:m -rø:l }\end{array}$ & $*\{$ hi:m+F $\}$ & & $*$ (io) & \\
\hline $\begin{array}{r}\text { b. *hi:m-e: -ro:l } \\
\text { hi:m-e: -rø:l }\end{array}$ & $*\{$ hi:m+F $\}$ & & $*(\mathrm{eo})$ & $*(\mathrm{i} . . . \mathrm{o})$ \\
\hline $\begin{array}{r}\text { c. *hi:m-e:-i -ro:l } \\
\text { hi:m-e:-i -rø:l }\end{array}$ & $*\{$ hi:m+F $\}$ & & $*($ io $)$ & $* *(\mathrm{i} / \mathrm{e} \ldots \mathrm{o})$ \\
\hline $\begin{array}{r}\text { d. hi:d -rø:l } \\
\text { *hi:d -rø:l }\end{array}$ & $*\{\mathrm{hi}: \mathrm{d}+\mathbf{B}\}$ & & $*($ io) & \\
\hline $\begin{array}{l}\text { e. hi:d-e: -ro:l } \\
\text { *hi:d-e: -rø:l }\end{array}$ & $*\{$ hi:d + B $\}$ & & $*(\mathrm{eo})$ & $*(\mathrm{i} . . . \mathrm{o})$ \\
\hline $\begin{array}{rr}\text { f. hi:d-e:-i -ro:l } \\
\text { *hi:d-e:-i -rø:l }\end{array}$ & $*\{$ hi:d+B $\}$ & & $*($ io $)$ & $* *(\mathrm{i} / \mathrm{e} \ldots \mathrm{o})$ \\
\hline
\end{tabular}

In the Appendix we show the analysis of some more complex cases involving most of the harmony constraints used in the analysis in which the harmony constraints ordered higher than HARUNI (HAR- $\mathrm{F}_{\mathrm{R}}(0)$ and $\mathrm{HAR}_{\mathrm{L}} \mathrm{F}_{\mathrm{L}}(1)$, see Section 4.5 below), are not violated and therefore HARUNI makes the selection of the grammatical forms).

\subsection{Some violations of Harmonic Uniformity}

We have noted at the end of Section 3 that some systematic violations of Harmonic Uniformity do occur. One such case we will briefly consider here concerns forms with invariant suffixes that have a harmonic (back) vowel. The number of these suffixes is extremely low. The most frequent one is temporal -kor, but there are others e.g. denominal verbalizers -all and -ol shown in the forms in (16i) below. Whenever such a suffix occurs in a form and is followed by a harmonically alternating suffix, the latter suffix takes its back harmonic alternant irrespective of the harmonic properties of the root, 
i.e. Harmonic Uniformity is violated when the root otherwise has forms with front harmonic suffix alternants in its paradigm, e.g. $\mathbf{z Z}$ (16i:a) 'this', debyt- 'beginning' (16i:b) and tsuryk: 'retreat' (16i:c). We have already seen in (9) that HAR- $\mathrm{F}_{\mathrm{R}}(0)$ must be ordered above HARUNI. This ranking also has the desired effect here because, ultimately, this is the constraint the makes the selection of grammatical forms here even when the winning candidate forms violate HARUNI (because the paradigms of $\mathbf{\varepsilon z}, \mathbf{d} \mathbf{d} \mathbf{b} \mathbf{b} \mathbf{t}-$, tsuryk: (otherwise) only contain listed forms with front suffix alternants).

(16i) Violating Harmonic Uniformity with stems containing invariant back suffixes

\begin{tabular}{|c|c|c|c|c|c|c|}
\hline $\begin{array}{c}S T E M+A B L \\
\text { STEM+PRESP }\end{array}$ & $\begin{array}{c}\text { HAR-F } \\
(0) \\
\left({ }^{*} \mathrm{BF}\right)\end{array}$ & $\begin{array}{c}\text { HAR } \mathrm{F}_{\mathrm{L}} \\
(1) \\
\left({ }^{*} \mathbf{F V B}\right)\end{array}$ & HARUNI & $\begin{array}{c}\mathrm{HAR}-\mathrm{F}_{\mathrm{R}} \\
(\geq 2) \\
{ }^{*} \mathbf{B V V}^{+} \mathbf{F}\end{array}$ & $\begin{array}{c}\text { HAR-N } \\
(0) \\
(* N B)\end{array}$ & $\begin{array}{c}\operatorname{HAR}-\varepsilon_{\mathrm{L}} \\
(\geq 1) \\
\left(* \varepsilon \mathbf{V}^{+} \mathbf{B}\right)\end{array}$ \\
\hline $\begin{array}{l}\text { a. ek-kor -to:l } \\
* \varepsilon k-k o r-t \varnothing: 1\end{array}$ & $*(\mathrm{\varnothing})$ & & $*\{\varepsilon(\mathrm{z})+\mathbf{F}\}$ & & & $*(\varepsilon \ldots o)$ \\
\hline $\begin{array}{r}\text { c. debyt-a:l -o: } \\
\text { *debyt-a:l -ø: }\end{array}$ & $*(\mathrm{a} \emptyset)$ & $*(\mathrm{y} \ldots \mathrm{o})$ & $*\{\mathrm{~d} .+\mathbf{F}\}$ & & & $*(\varepsilon \ldots o)$ \\
\hline $\begin{array}{l}\text { d. tsuryk:-ol -o: } \\
\text { *tsuryk:-ol -Ø: }\end{array}$ & $*(\circ \varnothing)$ & $*(\mathrm{y} \ldots \mathrm{o})$ & $*\{$ ts. $+\mathbf{F}\}$ & *(u...Ø) & & \\
\hline
\end{tabular}

\section{SUMMARY}

In this paper we have argued against the traditional assumption of the role of morphology in Hungarian front/back harmony. We examined Harmonic Uniformity, an output-output paradigm uniformity constraint, which drives a more intricate interaction between phonological harmony and morphology. It affords a descriptively more accurate account of what a simple division between what is inside and outside a morphologically identified harmonic domain makes possible (which is usually assumed). We have given an OT analysis of front/back harmony and variation in front/back harmony focussing on the role of Harmonic Uniformity.

In (17) we can see the ordering of the constraints used in the analysis. In conclusion we make some comments about this ranking.

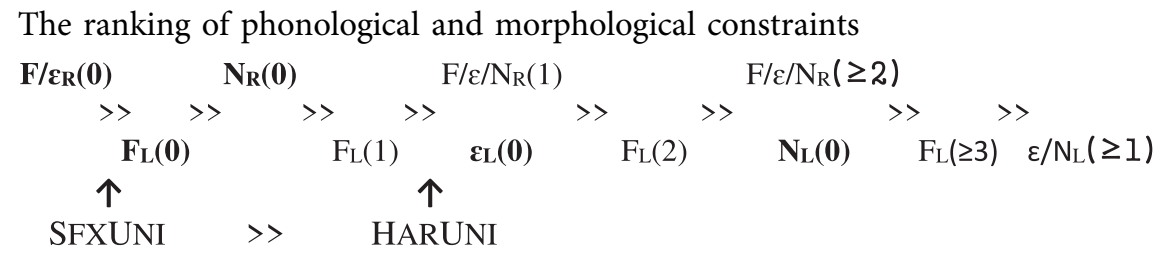

As can be seen in (17) the morphological constraints SFXUNI and HARUNI are interleaved with phonological constraints. They rank high but are not undominated by (some) phonological constraints, which means that suffix uniformity and the harmonic uniformity of paradigms have phonological limits set by harmony. These constraints also make it possible to account for differences in the harmonic behaviour of different morphemes that are identical in their vocalic makeup (lexical variation). 
In the OT analysis, the phonological (markedness) constraints distinguish three sets of vowels based on their harmonic behaviour: i. harmonic vowels (F: ø, ø:, y, y:; B: u, u:, o, o:, a, a:), ii. $\boldsymbol{\varepsilon}$, and iii. neutral vowels (N: i, i, e:) which reflects the intermediate status of $\varepsilon$ in neutrality. Some generalisations can be made about the ranking of these constraints. This is shown in formulae in (18), where we have always identified the harmony patterns the relevant constraints refer to.

$$
\begin{aligned}
& \text { Generalizations about the ranking of the harmony constraints } \\
& \text { Monotonic properties (universal): } \\
& \text { a. Locality: } \\
& \qquad X_{Y}(n) \geq \geq X_{Y}(n+1) \text {, where } X \in\{\mathrm{F}, \varepsilon, \mathrm{N}\} ; Y \in\{\mathrm{R}, \mathrm{L}\} \text {; for all } n \\
& \text { b. Height Effect: } \\
& \qquad \mathrm{F}_{Y}(n) \geq \geq \varepsilon_{Y}(n) \geq \geq \mathrm{N}_{Y}(n) \text {, where } Y \in\{\mathrm{R}, \mathrm{L}\} \text {; for all } n \\
& \text { Stipulations (language specific): } \\
& \text { c. Opacity of B: } \\
& \quad X_{\mathrm{R}}(n)>>\mathrm{F}_{\mathrm{L}}(n+1) \text { where } X \in\{\mathrm{F}, \varepsilon, \mathrm{N}\} \text {; for all } n \\
& \text { d. Opacity of F: } \\
& \quad \mathrm{F}_{\mathrm{L}}(n)>>X_{\mathrm{R}}(n+1) \text { where } X \in\{\mathrm{F}, \varepsilon, \mathrm{N}\} \text {; for } n=0,1,2 \\
& \text { e. Transparency of } \mathrm{N} \text { : } \\
& \quad X_{\mathrm{R}}(n+1)>>\mathrm{N}_{\mathrm{L}}(n) \text { where } X \in\{\mathrm{F}, \varepsilon, \mathrm{N}\} \text {; for all } n \\
& \text { f. F and } \varepsilon \text { behave similarly in suffixes: } \\
& \quad \mathrm{F}_{\mathrm{R}}(n)=\varepsilon_{\mathrm{R}}(n) \text { for all } n \\
& \text { g. Non-final } \varepsilon \text { and } \mathrm{N} \text { behave similarly in roots: } \\
& \varepsilon_{\mathrm{L}}(n)=\mathrm{N}_{\mathrm{L}}(n) \text {, where for all } n>0
\end{aligned}
$$

Some of the rankings (18ab) are universal (follow from some aspect of monotonicity) and/or cross-linguistic facts: ${ }^{45}$ a less local constraint (measured in the number of vowels) cannot rank higher than more local one that has the same orientation (18a); given constraints whose orientation and locality parameters are identical the one that refers to harmonic vowels always ranks higher than the one the refers to neutral ones and the one that refers to $\varepsilon$ is in between (18b). Of the language-specific constraints the ordering in (18cd) and (18e) express the opacity of harmonic vowels and the transparency of neutral vowels. (18f) and (18g) model the special status of $\varepsilon$. (18f): $\varepsilon$ counts as non-neutral (harmonic) in suffixes (it always alternates harmonically), i.e., the right-oriented harmony constraints are the same for $F$ and $\varepsilon\left(F / \varepsilon_{R}\right)$. (18g): $\varepsilon$ counts as neutral within stems in non-stem-final positions (non-local left-oriented harmony: $\varepsilon /$ $\mathrm{N}_{\mathrm{L}}(\geq 1)$ ).

\section{FUNDING SOURCE}

This work was supported by the National Scientific Grant NKFI-119863 'Experimental and theoretical investigations of vowel harmony patterns'.

\footnotetext{
${ }^{45}$ For (18b) see e.g. Anderson (1980).
} 


\section{REFERENCES}

Ackerman, Farrell, James P. Blevins and Robert Malouf. 2009. Parts and wholes: Implicative patterns in inflectional paradigms. In James P. Blevins and Juliette Blevins (eds.) Analogy in grammar: Form and acquisition. Oxford: Oxford University Press. 54-82.

Anderson, Lloyd B. 1980. Using asymmetrical and gradient data in the study of vowel harmony. In Robert M. Vago (ed.) Issues in vowel harmony. Amsterdam: John Benjamins. 271-340.

Anttila, Arto. 2007. Variation and optionality. In Paul de Lacy (ed.) The Cambridge handbook of phonology. Cambridge: Cambridge University Press. 519-536.

Archangeli, Diana and Douglas Pulleyblank. 2015a. Phonology without universal grammar. Frontiers in Psychology 6. 1229. https://doi.org/10.3389/fpsyg.2015.01229.

Archangeli, Diana and Douglas Pulleyblank. 2015b. Tonal allomorphy in Kinande. In Yuchau E. Hsiao and Lian-Hee Wee (eds.) Capturing phonological shades. Newcastle upon Tyne: Cambridge Scholars Publishing. 76-100.

Archangeli, Diana and Douglas Pulleyblank 2017. Phonology as an emergent system. In S. J. Hannahs and Anna R. K. Bosch (eds.) The Routledge handbook of phonological theory. London \& New York, NY: Routledge. 476-503.

Benua, Laura 1995. Identity effects in morphological truncation. In Jill Beckman, Laura Walsh Dickey and Suzanne Urbanczyk (eds.) University of Massachusetts Occasional Papers in Linguistics 18: Papers in Optimality Theory. Amherst, MA: Graduate Linguistic Student Association. 77-136.

Coetzee, Andries W. and Joe Pater. 2011. The place of variation in phonological theory. In John Goldsmith, Jason Riggle and Alan C. L. Yu (eds.) The handbook of phonological theory. 2nd edition. Malden, MA \& Oxford: Wiley-Blackwell. 401-434.

Fejes, László and Péter Rebrus 2017. Vegyes hangrendű tövek a Károli-bibliában [Mixed roots in the Károli Bible]. Paper presented at Nyelvelmélet és dialektológia 4. - A Károli-Biblia nyelve Conference. Pázmány Péter Catholic University, Budapest, 17-18 October, 2017.

Fejes, László and Péter Rebrus. 2019. Mennyire átlátszó az i? [How transparent is the vowel i?]. Hungarológiai Közlemények XX(4). 49-60.

Finkel, Raphael and Gregory Stump. 2009. Principal parts and degrees of paradigmatic transparency. In James P. Blevins and Juliette Blevins (eds.) Analogy in grammar: Form and acquisition. Oxford: Oxford University Press. 13-53.

Forró, Orsolya. 2013. Ingadozás a magyar elölségi harmóniában. Szempontok a variabilitás szinkróniájának és diakróniájának feltárásához és értelmezéséhez [Variation in palatal harmony in Hungarian: Approaches to the interpretation of synchronic and diachronic variability]. PhD dissertation. Pázmány Péter Catholic University, Piliscsaba.

Goldsmith, John A. 1990. Autosegmental and metrical phonology. Oxford: Blackwell.

Hayes, Bruce and Zsuzsa Cziráky Londe. 2006. Stochastic phonological knowledge: The case of Hungarian vowel harmony. Phonology 23. 59-104.

Hayes, Bruce, Kie Zuraw, Péter Siptár and Zsuzsa Londe. 2009. Natural and unnatural constraints in Hungarian vowel harmony. Language 85. 822-863.

Hulst, Harry van der and Jeroen van de Weijer. 1995. Vowel harmony. In John A. Goldsmith (ed.) The handbook of phonological theory. Cambridge, MA \& Oxford: Blackwell. 495-534.

Kager, René. 2000. Optimality Theory. Cambridge: Cambridge University Press. 
Kenstowicz, Michael. 2005. Paradigmatic uniformity and contrast. In Laura J. Downing, T. A. Hall and Renate Raffelsiefen (eds.) Paradigms in phonological theory. Oxford: Oxford University Press. 145-169.

Patay, Fanni. 2019. Similarity effects in vowel harmony. MA dissertation. Eötvös Loránd Tudományegyetem Budapest.

Patay, Fanni, Péter Rácz, Péter Rebrus and Miklós Törkenczy. 2019: Lexical effects outrank phonological biases in Hungarian morphophonological variation. Talk delivered at the 4th Conference on Experimental Approaches to Perception and Production of Language Variation (ExAPP), 26-28 September, Münster, Germany.

Péter, Rebrus, Péter Szigetvári and Miklós Törkenczy. 2017. Asymmetric variation. In Jeff Lindsey and Andrew Nevins (eds.) Sonic signatures. Amsterdam/Philadelphia, PA: John Benjamins Publishing Company. 163-187.

Prince, Alan and Paul Smolensky. 1993/2004. Optimality Theory: Constraint interaction in generative grammar. Manuscript. Rutgers University, New Brunswick, NJ \& University of Colorado, Boulder, CO. [Published by Oxford: Blackwell, 2004.]

Rebrus, Péter and Péter Szigetvári. 2016. Diminutives: Exceptions to Harmonic Uniformity. Catalan Journal of Linguistics 15. 101-119.

Rebrus, Péter and Péter Szigetvári. 2021. Diminutive formation in Hungarian. Acta Linguistica Academica 68(1-2).

Rebrus, Péter and Miklós Törkenczy. 2005. Uniformity and contrast in the Hungarian verbal paradigm. In Laura J. Downing, T. A. Hall and Renate Raffelsiefen (eds.) Paradigms in phonological theory. Oxford: Oxford University Press. 262-295.

Rebrus Péter and Miklós Törkenczy. 2008. Morfofonológia és a lexikon [Morphophonology and the lexicon]. In Ferenc Kiefer (ed.) Strukturális magyar nyelvtan IV. A lexikon. Budapest: Akadémiai Kiadó. 683-786.

Rebrus, Péter and Miklós Törkenczy. 2016b. A non-cumulative pattern in vowel harmony: a frequencybased account. In Gunnar Ólafur Hansson, Ashley Farris-Trimble, Kevin McMullinand and Douglas Pulleyblank (eds.) Proceedings of the 2015 Annual Meeting on Phonology. Washington, DC: Linguistic Society of America. 1-12. http://dx.doi.org/10.3765/amp.v3i0.3692.

Rebrus, Péter and Miklós Törkenczy. 2016c. Monotonicity and the limits of disharmony. In Adam Albright and Michelle A. Fullwood (eds.) Proceedings of the 2014 Annual Meeting on Phonology. Washington, DC: Linguistic Society of America. 1-12. http://dx.doi.org/10.3765/amp.v2i0.3769.

Rebrus, Péter and Miklós Törkenczy. 2017a. Co-patterns, subpatterns and conflicting generalizations in Hungarian vowel harmony. In Harry van der Hulst and Anikó Lipták (eds.) Approaches to Hungarian. Volume 15: Papers from the 2015 Leiden Conference. Amsterdam/Philadelphia, PA: John Benjamins Publishing Company. 135-156.

Rebrus, Péter and Miklós Törkenczy. 2017b. Gradient harmonicity in compounds. In Karen Jesney, Charlie O'Hara, Caitlin Smith and Rachel Walker (eds.) Proceedings of the 2016 Annual Meeting on Phonology. Washington, DC: Linguistic Society of America. 1-12. http://dx.doi.org/10.3765/amp.v4i0.4007.

Rebrus, Péter and Miklós Törkenczy. 2019. Magyar harmónia: a dolgok állása [Harmony in Hungarian: The current state of play]. Általános Nyelvészeti Tanulmányok XXXI. 233-333.

Rebrus, Péter and Péter Szigetvári and Miklós Törkenczy. 2012. Dark secrets of Hungarian vowel harmony. In Eugeniusz Cyran, Henryk Kardela and Bogdan Szymanek (eds.) Sound, structure and sense: Studies in memory of Edmund Gussmann. Lublin: Wydawnictwo KUL. 491-508.

Rebrus, Péter, Péter Szigetvári and Miklós Törkenczy. 2020. Variation, the Height effect, and disharmony in Hungarian front/back harmony. In Hyunah Baek, Chikako Takahashi and Alex Hong-Lun Yeung (eds.) 
Proceedings of the 2019 Annual Meeting on Phonology. Washington, DC: Linguistic Society of America. 1-10. https://doi.org/10.3765/amp.v8i0.4750.

Ringen, Catherine and Miklós Kontra. 1989. Hungarian neutral vowels. Lingua 78. 181-191.

Siptár, Péter, Miklós Törkenczy. 2000. The phonology of Hungarian. Oxford/New York, NY: Oxford University Press.

Steriade, Donca. 1999. Lexical conservatism in French adjectival liaison. In Barbara Bullock, Marc Authier and Lisa Reed (eds.) Formal perspectives in Romance linguistics. Amsterdam: John Benjamins. 243-270. Steriade, Donca. 2000. Paradigm uniformity and the phonetics/phonology boundary. In Janet B. Pierrehumbert and Michael B. Broe (eds.) Papers in Laboratory Phonology 6. Cambridge: Cambridge University Press. 313-334.

Steriade, Donca. 2008. A pseudo-cyclic effect in Romanian morphophonology. In Asaf Bachrach and Andrew Nevins (eds.) Inflectional identity. Oxford: Oxford University Press. 313-358.

Törkenczy, Miklós. 2011. Hungarian vowel harmony. In Marc van Oostendorp, Colin J. Ewen, Elizabeth Hume and Keren Rice (eds.) The Blackwell companion to phonology. Malden, MA \& Oxford: WileyBlackwell. 2963-2990.

Törkenczy, Miklós. 2019. Hungarian vowel harmony: Beyond the standard data set. Talk delivered to Massachusetts Institute of Technology, Cambridge, MA, 16 October, 2019.

Törkenczy, Miklós. 2021. Hungarian vowel harmony. In Mark Aronoff (ed.) Oxford bibliographies in linguistics. New York, NY: Oxford University Press. http://www.oxfordbibliographies.com/obo/page/linguistics.

Törkenczy, Miklós, Péter Rebrus and Péter Szigetvári. 2013. Harmony that cannot be represented. In Johan Brandtler, Valéria Molnár and Christer Platzack (eds.) Approaches to Hungarian. Volume 13: Papers from the 2011 Lund Conference. Amsterdam/Philadelphia, PA: John Benjamins. 229-252.

\section{APPENDIX}

Complex cases: forms obeying Harmonic Uniformity

\begin{tabular}{|c|c|c|c|c|c|c|c|c|}
\hline $\begin{array}{c}\text { STEM+ABL } \\
\text { STEM+PRESP }\end{array}$ & HARUNI & $\left|\begin{array}{c}\text { HAR- } F_{\mathrm{R}} \\
(1) \\
\left({ }^{*} \mathbf{B V F}\right)\end{array}\right|$ & $\begin{array}{c}\text { HAR- } \varepsilon_{L} \\
(0) \\
\left(*_{\varepsilon} \mathbf{B}\right)\end{array}$ & $\begin{array}{c}{\text { HAR }-F_{L}} \\
(2) \\
*(\mathbf{F V V B})\end{array}$ & $\begin{array}{c}\text { HAR- } F_{R} \mathbf{1} \\
(\geq 2) \\
* \mathbf{B V} \geq 2 \mathbf{F}\end{array}$ & $\begin{array}{c}\text { HAR- } \mathrm{N}_{\mathrm{L}} \\
(0) \\
\left({ }^{*} \mathrm{NB}\right)\end{array}$ & $\begin{array}{c}\text { HAR- } F_{L} \\
(\geq 3) \\
* \mathbf{F V} \geq 3 \mathbf{B}\end{array}$ & $\begin{array}{c}\operatorname{HAR}-\mathrm{N}_{\mathrm{L}} \\
(\geq 1) \\
* \mathbf{N V}^{+} \mathbf{B}\end{array}$ \\
\hline $\begin{array}{r}\text { a. krø:zus-i -to:l } \\
\text { *krø:zus-i -tø:l } \\
\end{array}$ & $*\{\mathrm{k} .+\mathbf{B}\}$ & $*(\mathrm{u} \ldots \varnothing)$, & & 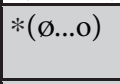 & & $*$ (in) & & \\
\hline $\begin{array}{r}\text { b. krø:zus-e:-i -to:l } \\
\quad * \text { krø:zus-e:-i -tø:l } \\
\end{array}$ & $*\{\mathrm{k} .+\mathbf{B}\}$ & & & & *(u...ø) & $*$ (io) & $*(\varnothing \ldots o)$ & $*(\mathrm{e} \ldots \mathrm{o})$ \\
\hline $\begin{array}{l}\text { c. ødipus-e: -to:l } \\
\text { *ødipus-e: -tø:l }\end{array}$ & $*\{\varnothing .+\mathbf{B}\}$ & *(u...ø) & & & *(u...ø) & ) & $*(\varnothing \ldots . .0)$ & $*(\mathrm{i} \ldots \mathrm{o})$ \\
\hline $\begin{array}{r}\text { d. ødipus-e:-i -to:l } \\
* \varnothing \text { dipus-e:-i -tø:l } \\
\end{array}$ & $*\{\varnothing .+\mathbf{B}\}$ & $\pi$ & & & *(u...ø) & $*$ (io) & $*(\varnothing \ldots o)$ & $* *(\mathrm{i} / \mathrm{e} \ldots \mathrm{o})$ \\
\hline $\begin{array}{l}\text { e. tsøno:zis-e: -to:l } \\
* \text { tsøno:zis-e: -tø:l } \\
\end{array}$ & $*\{\varnothing .+\mathbf{B}\}$ & 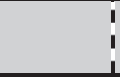 & & & *(o... & $*(\mathrm{eo})$ & & $*(\mathrm{i} \ldots \mathrm{o})$ \\
\hline
\end{tabular}

Open Access. This is an open-access article distributed under the terms of the Creative Commons Attribution 4.0 International License (https://creativecommons.org/licenses/by/4.0/), which permits unrestricted use, distribution, and reproduction in any medium, provided the original author and source are credited, a link to the CC License is provided, and changes - if any - are indicated. (SID_1) 